\title{
Glucose-Lowering Drugs and Fracture Risk-a Systematic Review
}

Citation for published version (APA):

Al-Mashhadi, Z., Viggers, R., Fuglsang-Nielsen, R., de Vries, F., van den Bergh, J. P., Harsløf, T., Langdahl, B., Gregersen, S., \& Starup-Linde, J. (2020). Glucose-Lowering Drugs and Fracture Risk-a Systematic Review. Current Osteoporosis Reports, 18(6), 737-758. https://doi.org/10.1007/s11914-02000638-8

Document status and date:

Published: 01/12/2020

DOI:

10.1007/s11914-020-00638-8

Document Version:

Publisher's PDF, also known as Version of record

Document license:

Taverne

Please check the document version of this publication:

- A submitted manuscript is the version of the article upon submission and before peer-review. There can be important differences between the submitted version and the official published version of record.

People interested in the research are advised to contact the author for the final version of the publication, or visit the DOI to the publisher's website.

- The final author version and the galley proof are versions of the publication after peer review.

- The final published version features the final layout of the paper including the volume, issue and page numbers.

Link to publication

\footnotetext{
General rights rights.

- You may freely distribute the URL identifying the publication in the public portal. please follow below link for the End User Agreement:

www.umlib.nl/taverne-license

Take down policy

If you believe that this document breaches copyright please contact us at:

repository@maastrichtuniversity.nl

providing details and we will investigate your claim.
}

Copyright and moral rights for the publications made accessible in the public portal are retained by the authors and/or other copyright owners and it is a condition of accessing publications that users recognise and abide by the legal requirements associated with these

- Users may download and print one copy of any publication from the public portal for the purpose of private study or research.

- You may not further distribute the material or use it for any profit-making activity or commercial gain

If the publication is distributed under the terms of Article $25 \mathrm{fa}$ of the Dutch Copyright Act, indicated by the "Taverne" license above, 


\title{
Glucose-Lowering Drugs and Fracture Risk—a Systematic Review
}

\author{
Z. Al-Mashhadi ${ }^{1,2} \cdot$ R. Viggers ${ }^{3,4} \cdot$ R. Fuglsang-Nielsen ${ }^{1,5} \cdot$ F. de Vries ${ }^{6,7}$ • J. P. van den Bergh ${ }^{8,9,10} \cdot$ T. Harsløf ${ }^{11}$. \\ B. Langdahl ${ }^{2,11} \cdot$ S. Gregersen ${ }^{1,11} \cdot$ Jakob Starup-Linde ${ }^{1,11}$
}

Accepted: 24 October 2020 / Published online: 9 November 2020

(C) Springer Science+Business Media, LLC, part of Springer Nature 2020

\begin{abstract}
Purpose of Review Diabetes mellitus (DM) is associated with increased fracture risk. The aim of this systematic review was to examine the effects of different classes of glucose-lowering drugs on fracture risk in patients with type $2 \mathrm{DM}$. The heterogeneity of the included studies did not allow formal statistical analyses.

Recent Findings Sixty studies were included in the review. Metformin, dipeptidylpeptidase-IV inhibitors, glucagon-like peptide1 receptor agonists, and sodium-glucose cotransporter 2-inhibitors do not appear to increase fracture risk. Results for insulin and sulphonylureas were more disparate, although there may be an increased fracture risk related to hypoglycemia and falls with these treatments. Glitazones were consistently associated with increased fracture risk in women, although the evidence was sparser in men.

Summary New glucose-lowering drugs are continuously being developed and better understanding of these is leading to changes in prescription patterns. Our findings warrant continued research on the effects of glucose-lowering drugs on fracture risk, elucidating the class-specific effects of these drugs.
\end{abstract}

Keywords Type 2 diabetes · Fracture · Glucose-lowering drugs · Antidiabetics · Glitazones · Insulin · Systematic review

\section{Introduction}

Diabetes mellitus $(\mathrm{DM})$ is associated with an increased risk of fracture $[1 \bullet \cdot$. In patients with type $1 \mathrm{DM}(\mathrm{T} 1 \mathrm{D})$, the fracture risk may be increased as much as sevenfold compared to subjects without DM $[1 \bullet \bullet]$, whereas the risk in patients with type 2 DM (T2D) is 1.3 -fold increased [1••]. In T2D, the increased risk of fracture is not explained by a lower bone mineral density (BMD); on the contrary, BMD is often reported to be higher in T2D compared to controls $[1 \bullet \bullet]$.

Although the mechanisms behind increased fracture rates in DM are not fully uncovered, ongoing research has suggested that bone deteriorates in DM due to structural changes in bone with increased cortical porosity [2] and alterations in

This article is part of the Topical Collection on Bone and Diabetes

Jakob Starup-Linde

jakolind@rm.dk

1 Steno Diabetes Center Aarhus, Aarhus University Hospital, Aarhus, Denmark

2 Department of Clinical Medicine, Aarhus University, Aarhus, Denmark

3 Steno Diabetes Center North Jutland, Aalborg University Hospital, Aalborg, Denmark

4 Department of Clinical Medicine, Aalborg University, Aalborg, Denmark

5 Department of Internal Medicine, Regional Hospital Horsens, Horsens, Denmark
6 Department of Clinical Pharmacy and Toxicology, Maastricht University Medical Centre+, Maastricht, The Netherlands

7 Department of Pharmacoepidemiology and Clinical Pharmacology, Utrecht Institute for Pharmaceutical Sciences, Utrecht, The Netherlands

8 Department of Internal Medicine, Maastricht University Medical Center+, Maastricht, The Netherlands

9 Department of Internal Medicine, VieCuri Medical Centre, Venlo, The Netherlands

10 Faculty of Medicine and Life Sciences, University Hasselt, Hasselt, Belgium

11 Department of Endocrinology and Internal Medicine, Aarhus University Hospital, Palle Juul Jensens Boulevard 99, 8220 Aarhus N, Denmark 
the bone collagen as a result of the accumulation of advanced glycation end-products [3], or due to low bone turnover causing micro-fractures which may lead to fractures despite relatively high BMD [4]. Furthermore, characteristics and severity of diabetes have been investigated. Although diabetes-related complications are associated with fractures, patients without complications also have an increased fracture risk [5]. The duration of diabetes is associated with fracture risk in some studies [6]; however, in the studies aiming to investigate T2D exclusively, some patients with T1D may have been included [7]. Falls and hypoglycemia are less well investigated in DM due to underreporting and information bias [8]. Both falls and hypoglycemia are associated with fractures; however, they do not fully explain the fracture rates in T1D and T2D [9].

Thus, the increased fracture risk may be increased due to several factors. New glucose-lowering treatments for T2D are being developed at a rapid pace, with some of these showing beneficial effects on renal and cardiovascular outcomes. However, glucose-lowering therapies may also influence fracture risk. Metformin is recognized as the first-line treatment of T2D, and second-line treatment consist of insulin, dipeptidylpeptidase-IV inhibitors (DPP-IVis), sodium-glucose cotransporter 2 inhibitors (SGLT2-is), glucagon-like peptide-1 receptor agonists (GLP-1 RAs), glitazones, and sulphonylureas. Recently, SGLT2-is and GLP-1 RAs have become recommended treatments in individuals with $\mathrm{T} 2 \mathrm{D}$ and cardiovascular disease, and SGLT2-is are also recommended to prevent progression of chronic kidney disease (estimated glomerular filtration rate 30 to $\leq 60 \mathrm{ml} / \mathrm{min}$ ) [10]. This systematic review aims to examine the evidence on the effects of glucose-lowering drugs on fracture risk in patients with T2D.

\section{Methods}

The PRISMA guidelines were followed [11]. A systematic literature search was conducted using Medline at PubMed (1966-2020) in January 2020 and last updated on February 27,2020 . Studies were deemed eligible for inclusion if they investigated associations between use of glucose-lowering drugs and fracture risk in patients with T2D. The following types of studies were included in the review: observational studies, randomized controlled trials (RCTs), meta-analyses containing at least one RCT that was not included in the literature search. Studies were not excluded on the basis of language or publication date. The glucose-lowering drugs that were investigated were insulins, metformin, sulphonylureass, glitazones, DPP-IVis, GLP-1 RAs, and SGLT2-is.

Free-text search terms were used. The search terms were "diabetes and fracture" in combination with "insulin," "thiazolidinediones," "glitazones," "sglt-2," "sodium glucose cotransporter 2," “sglt2," “dpp-4," "dipeptidyl peptidase-4 inhibitors," "glucagon-like peptide-1," "glp1 ," "glucagon-like peptide 1 receptor agonist," "sulfonylurea," "sulphonylurea," or "metformin." In total, 1583 papers were identified. After excluding duplicates and evaluating title and abstract, 106 publications were assessed in full text. Of these, 60 publications were included in this review. Figure 1 provides a flow-chart for in-/exclusion of studies. Studies were excluded if the population was without diabetes, there was no investigation of glucose-lowering drugs, or fracture was not the outcome. Data were extracted by two reviewers, JSL and ZAM, and included publication year, data source, study design, investigated glucose-lowering drug, comparator (if applicable), population mean/median age, duration of follow-up, adjustment, and result of the study. The outcome measures included were as follows: number of fractures (prevalence), odds ratios (OR), relative risks, hazard ratios (HR), and incidence rates. The quality of each included study was evaluated by the level of evidence using levels of evidence (March 2009) by the Oxford Centre for Evidence-Based Medicine [12]. Furthermore, possible sources of bias in the various studies were evaluated to identify potential difficulties in the interpretation of their findings. In drawing up the conclusions, weight was given to the results of studies of higher order evidence and with limited bias. In this systematic review, we did not perform any statistical analysis due to differences in study design, drug of use, use of comparator, outcome, and duration of follow-up.

\section{Results}

In total, 60 studies were included. Table 1 presents the included studies and extracted data. Study designs were mainly cohorts $(N=33)$, but also case-control studies $(N=10)$, crosssectional studies $(N=2)$, RCTs $(N=6)$, and meta-analyses of RCTs were included $(N=8)$. Fourteen studies investigated multiple glucose-lowering drugs, two studies investigated sulphonylureas, six studies investigated insulins, eight studies investigated SGLT2-is, five studies investigated GLP-1 RAs, 11 studies investigated DPP-IVis, and 14 studies investigated glitazones. Metformin was examined in 15 studies, although primarily as a comparator for other drugs. The study sizes ranged between 223 [61] and 499,526 [60॰] participants, and the mean ages of the investigated populations ranged from 43 years [9] to 81 years [25]. The follow-up of the studies ranged between 12 weeks [47] and 20 years [22]. Thus, the studies were heterogenous in design, study size, age of participants, and follow-up. 
Fig. 1 Flow-chart for inexclusion of studies

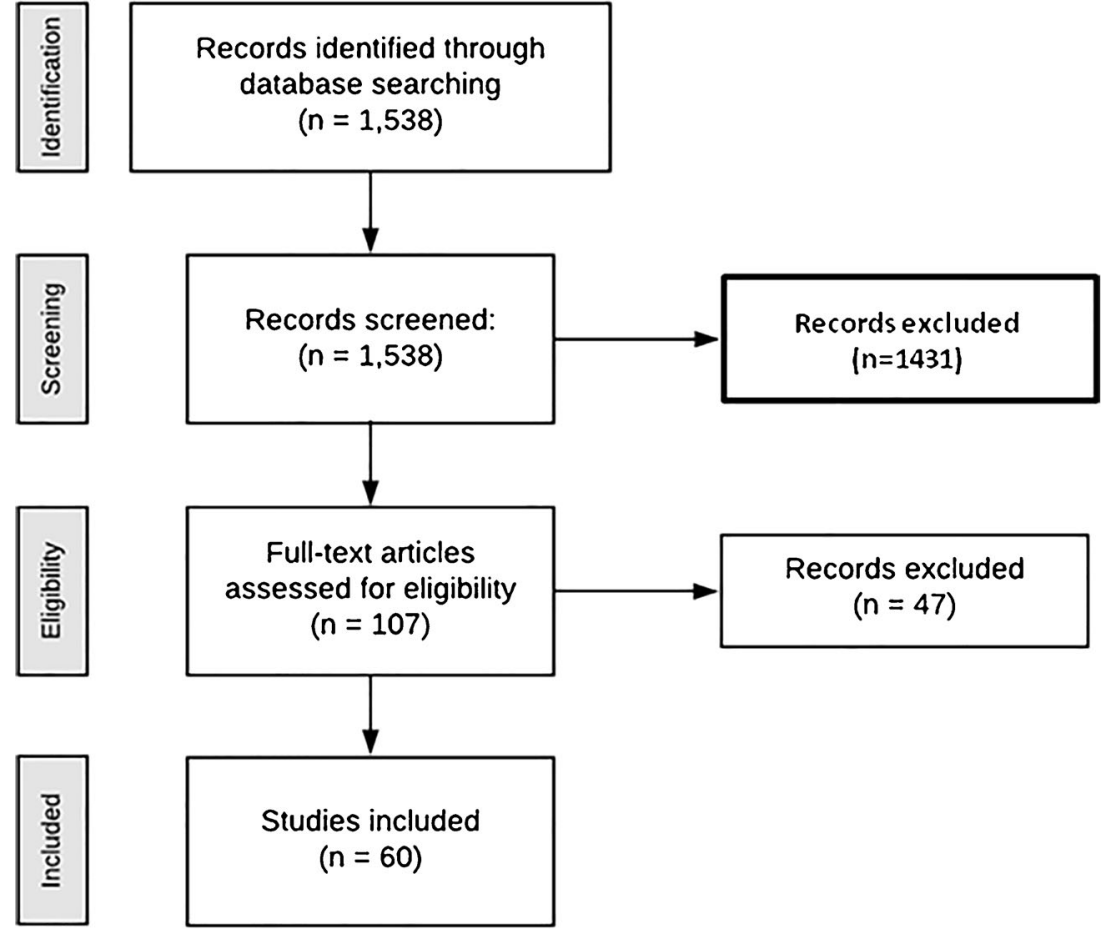

\section{Bias and Limitations}

The meta-analyses of RCTs were limited by short durations of follow-up [36, 42, 47]. Some included studies with a followup period as short as 12 weeks, and only one meta-analysis contained studies with follow-up periods up to 4 years [46, 67]. Due to these short follow-up periods, the numbers of fractures are relatively limited, making the interpretation of results difficult. An increased fracture risk with a short time to follow-up would suggest an increased risk of falls or hypoglycemia, whereas fractures due to bone fragility may require years to be detected. Furthermore, fractures were not the primary outcome in the analyses in these studies. In comparison to the cohort studies, the RCTs have limited study population sizes. The study by Kohler et al., which is a pooled analysis of 14 RCTs and a post hoc analysis of an additional RCT, included more than 14,000 subjects with T2D; however, the large pooled analysis $(n=12,620)$ had follow-up durations which varied between 8 days and 78 weeks (apart from one study with a duration of 2.6 years), whereas the relatively small post hoc analysis of participants from the EMPA-REG study $(n=1545)$ had the longest duration of follow-up of 208 weeks [37]. Thus, the RCTs and meta-analyses of RCTs have certain flaws in interpretations of fracture risk as a longterm consequence of glucose-lowering treatment. The observational studies are in general biased by confounding by (contra)-indication. Thus, one drug might have been chosen based on certain traits of patients. Furthermore, the comparator in both RCTs and observational studies is variable; non-diabetes subjects, T2D patients without pharmacological treatment, and T2D patients using different combinations of glucoselowering drugs. A general concern regarding cohort studies utilizing registries is whether the comparator constitutes a different group of T2D patients. The T2D population is comprised of participants with very different characteristics, from patients with normal body mass index (BMI) to very obese individuals, from patients with several comorbidities to patients with few, and the treatment may differ in regard to the severity of diabetes. Also, many patients are treated with three or four glucose-lowering drugs. Thus, the cohort studies may compare patients with less severe diabetes (first- or secondline therapy) with more severe diabetes (three or more drugs). Another possible bias of cohort studies is that some studies may include patients with T1D among the insulin users; this bias would overestimate the risk of fracture in insulin users as the relative fracture risk is higher in T1D compared to T2D. Some cohort studies follow patients before the introduction of treatment and thus the patients need to have survived a period before treatment to be included in the study. This can introduce immortal time bias, which is recognized in one of the studies included in this systematic review [48, 72]. In addition, if drug effects on fracture are expected to arise from alterations in bone tissue, a lag time after drug initiation would be expected [73]. Although this lag time is ill-defined, short follow-up durations would not be sufficient to explore bone-related effects but perhaps instead only fall-related effects on fracture risk.

Finally, several included studies have drawn on data from the same data sources, permitting some level of reporting bias. However, since these studies were performed at different 


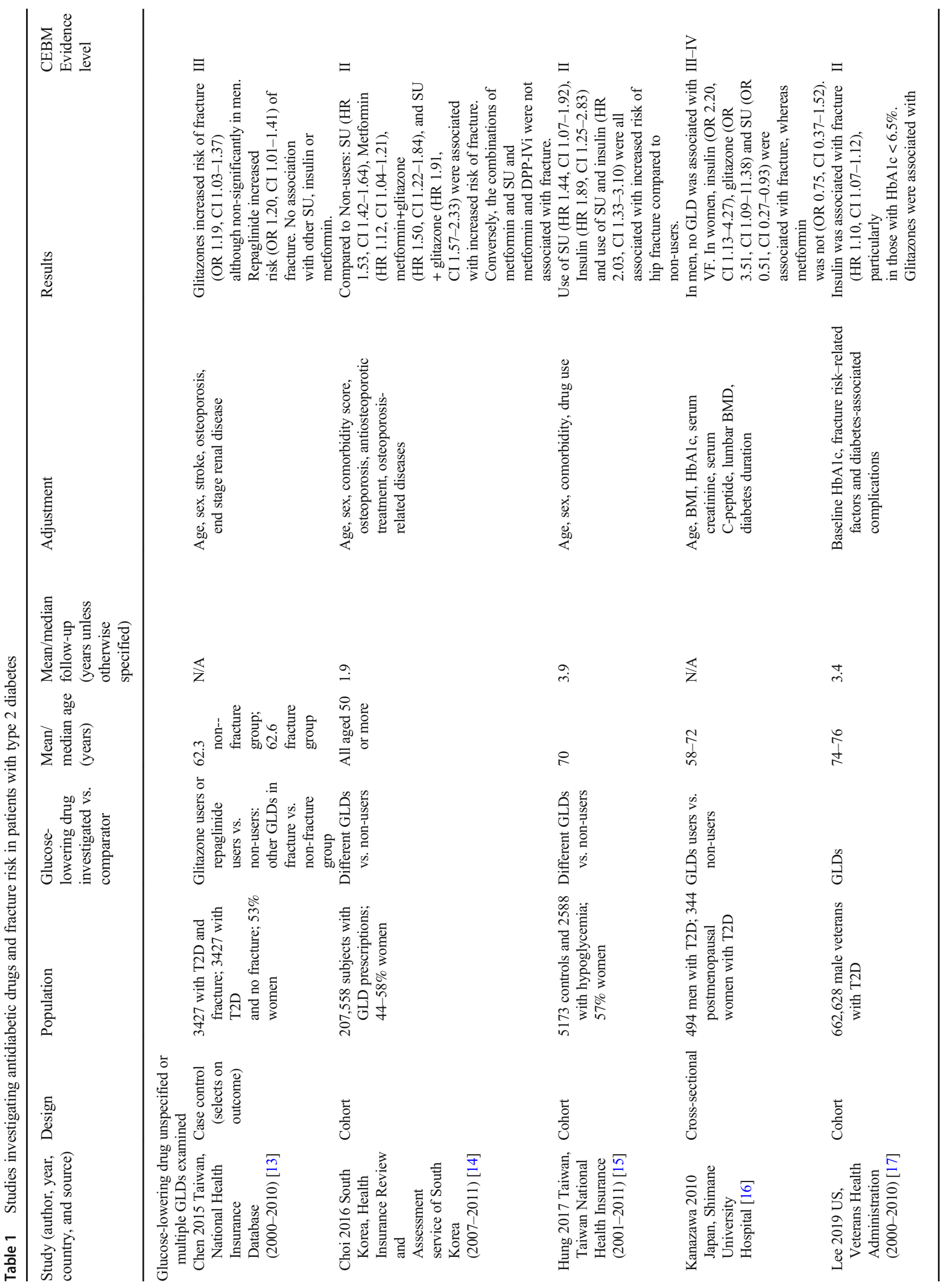




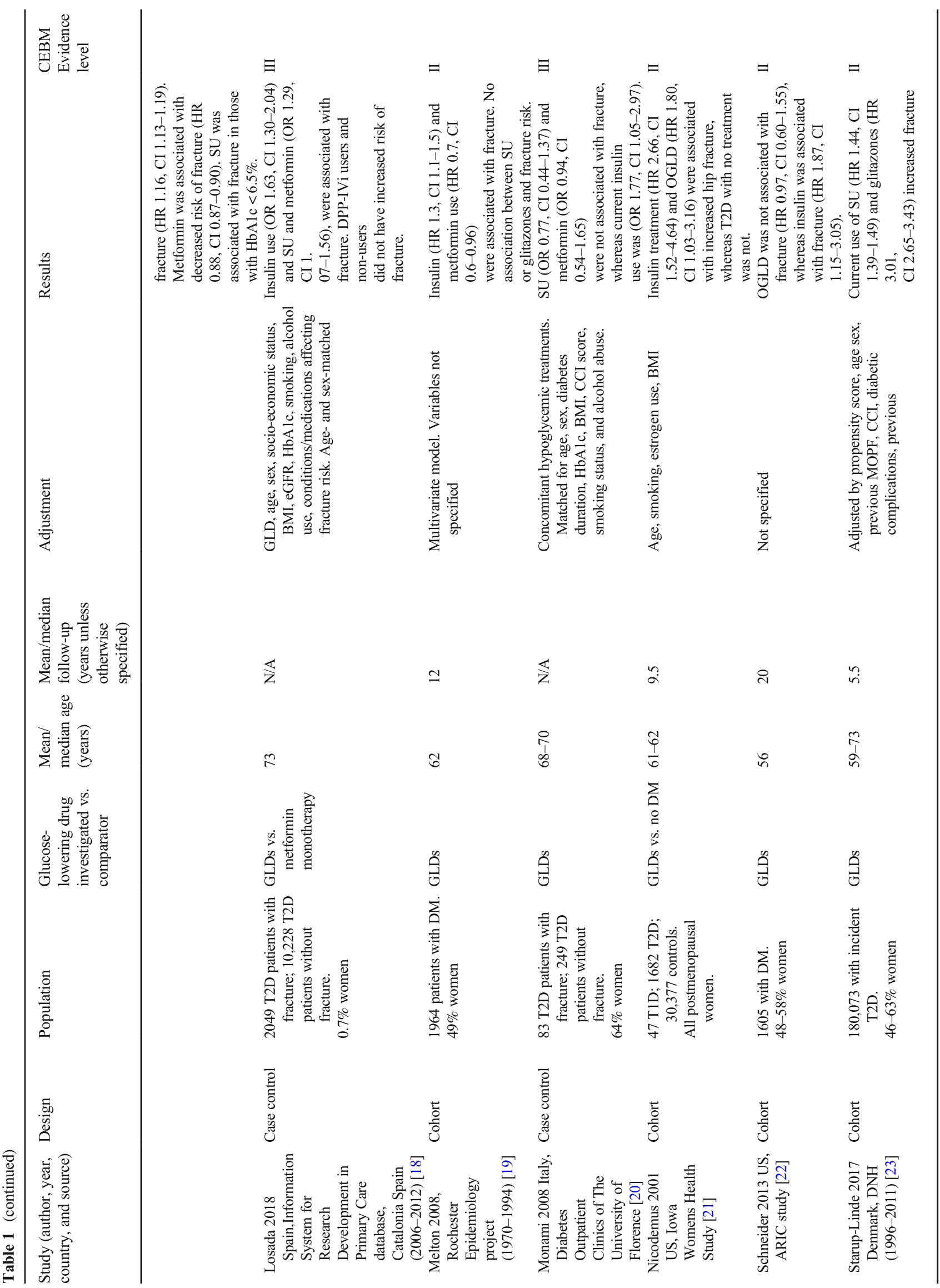




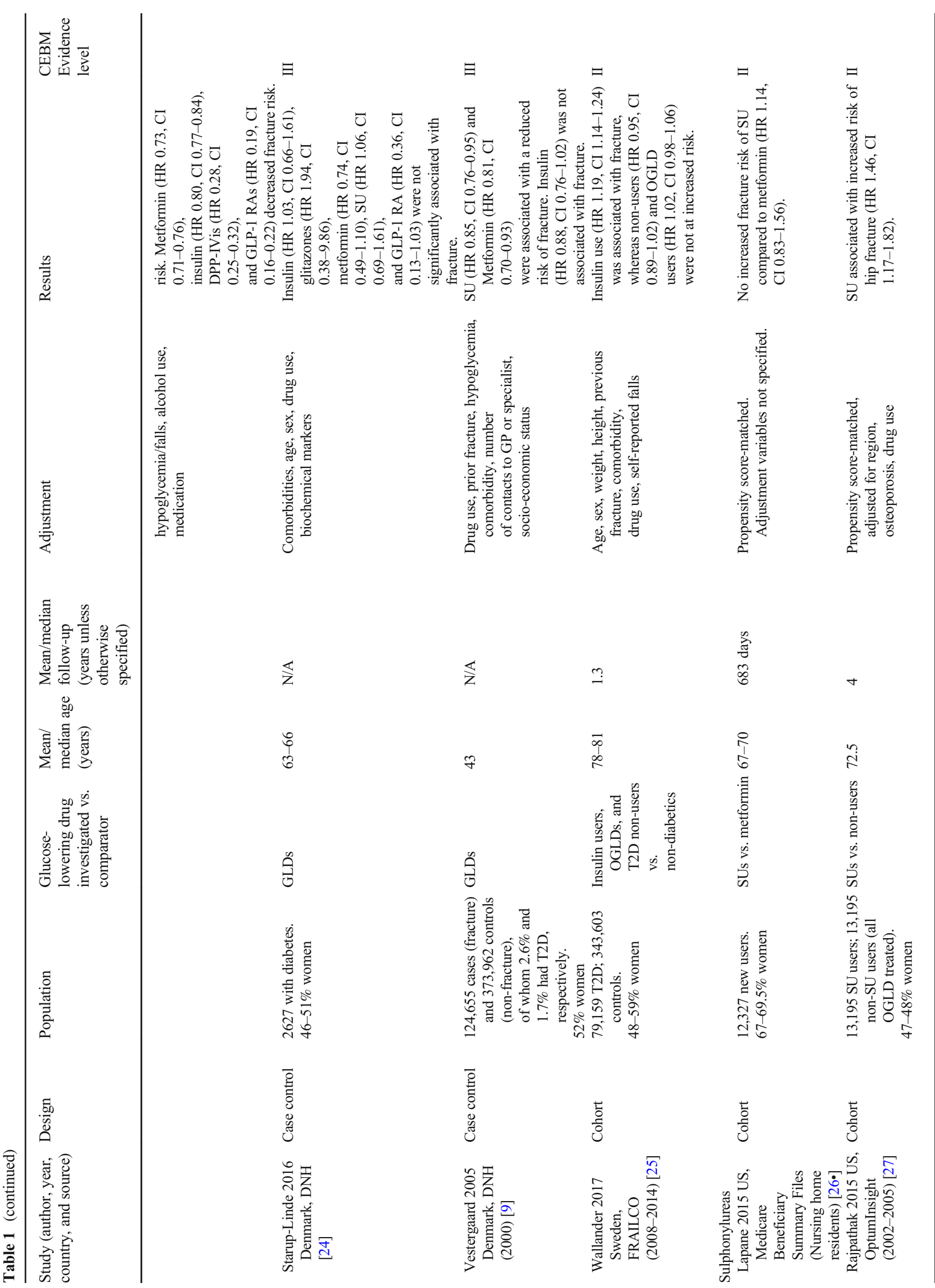




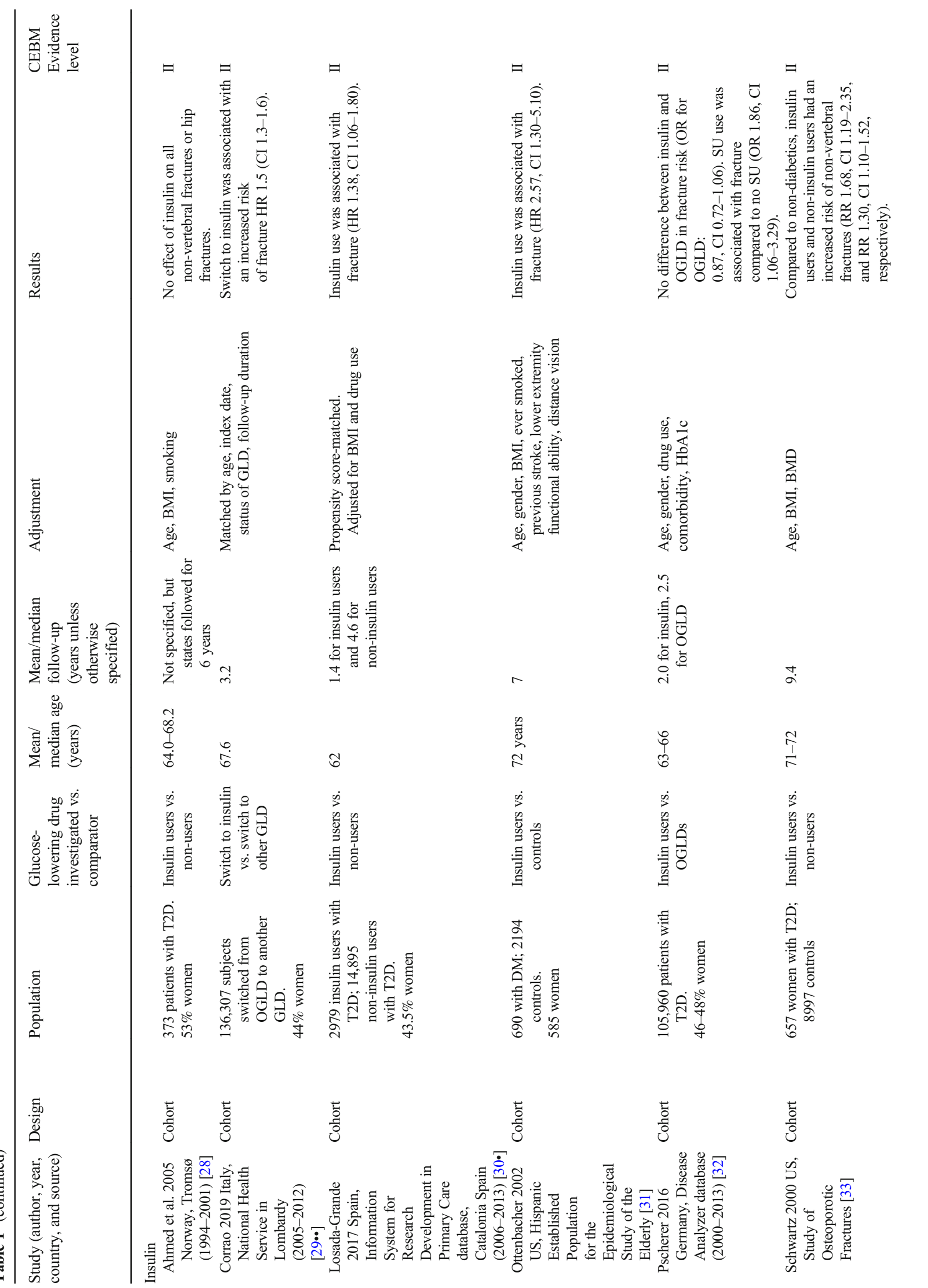




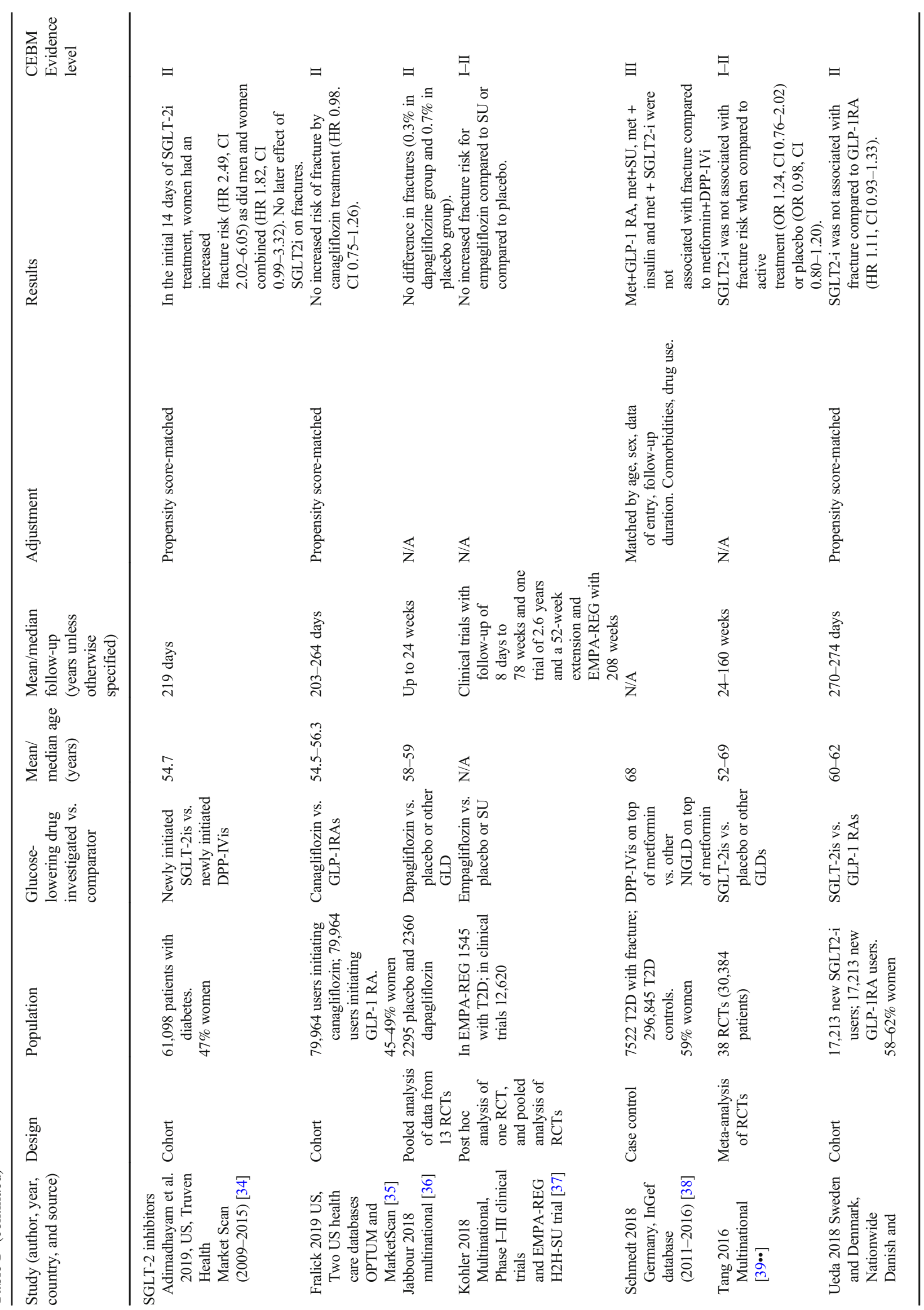




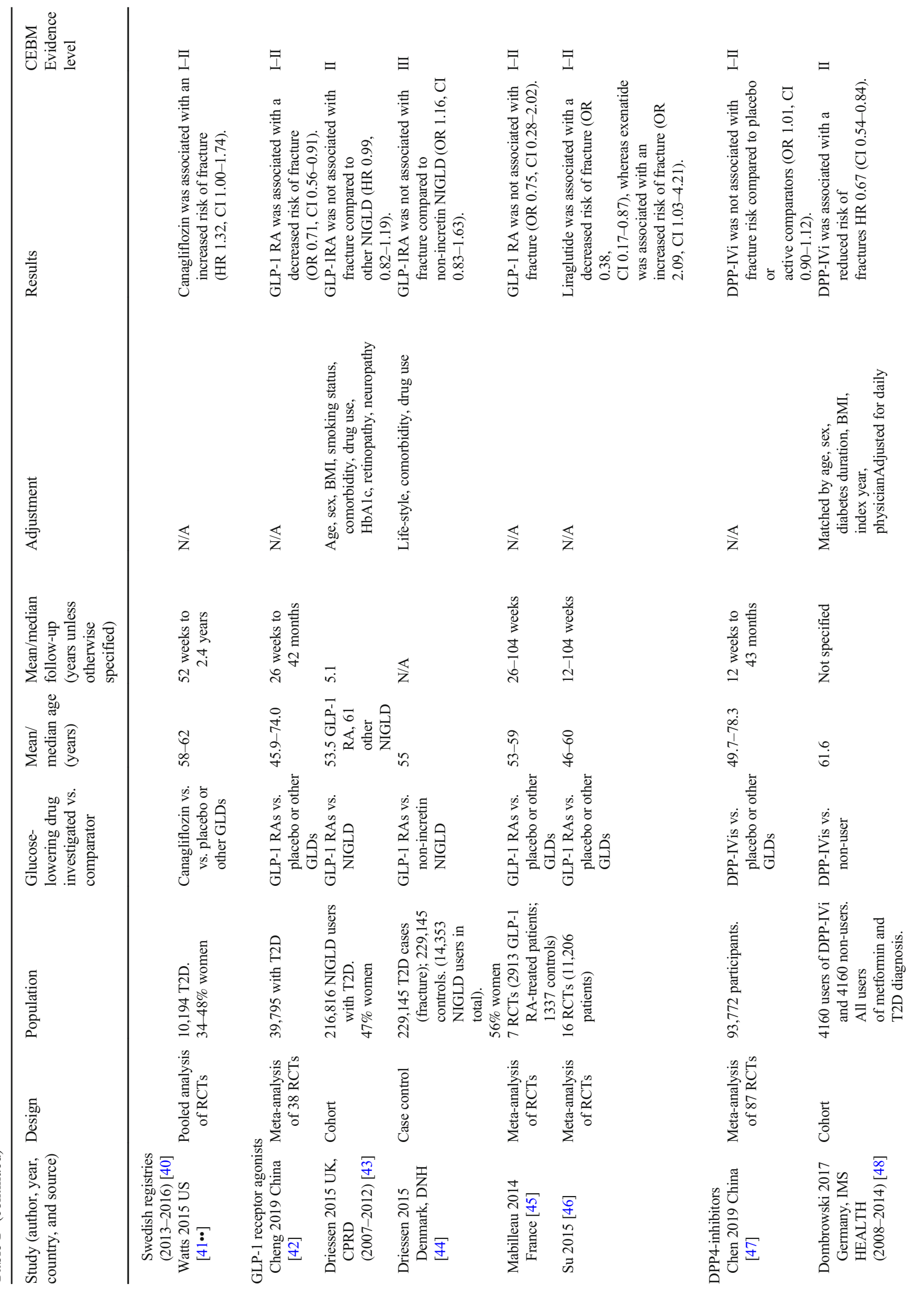




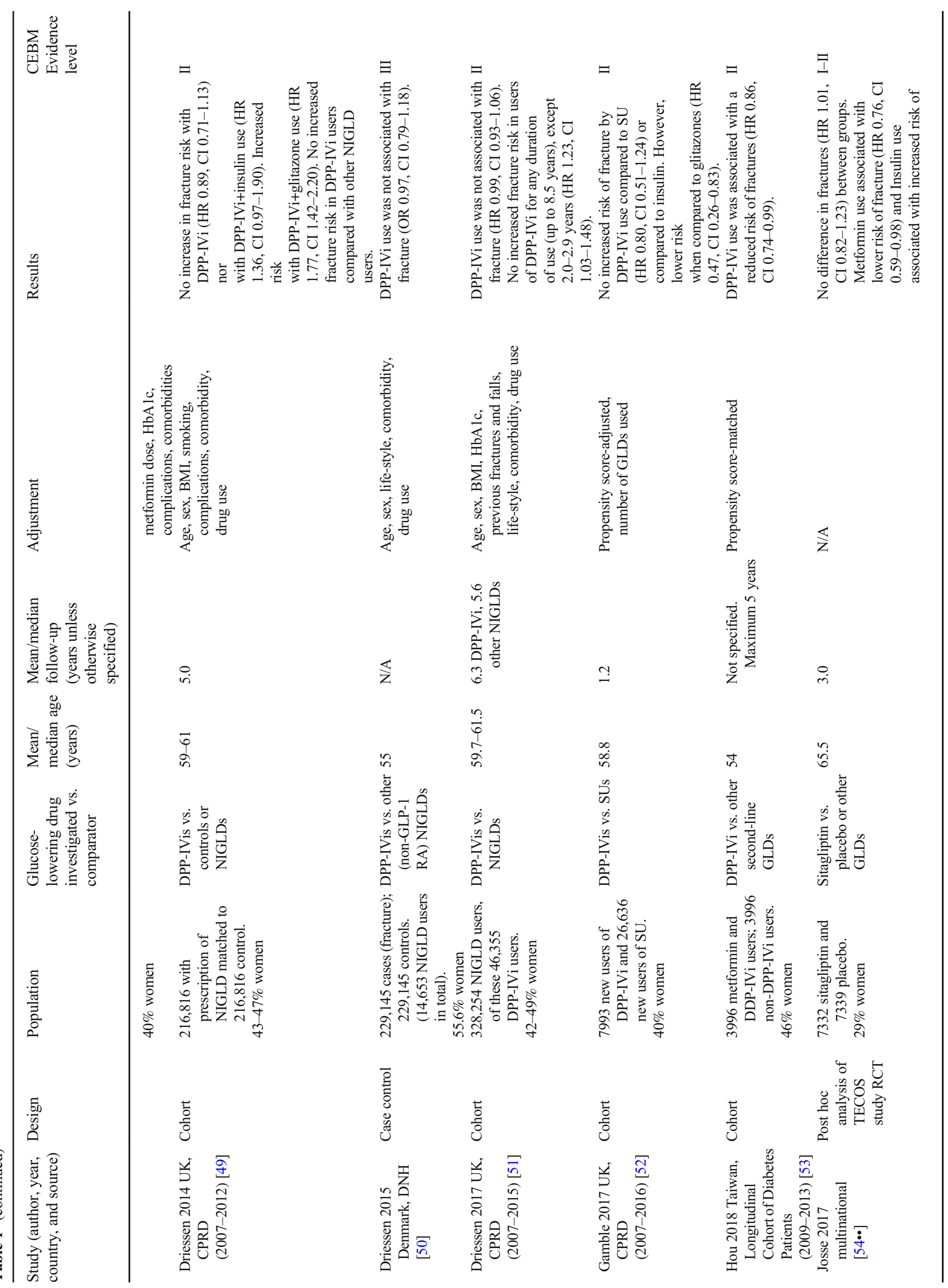




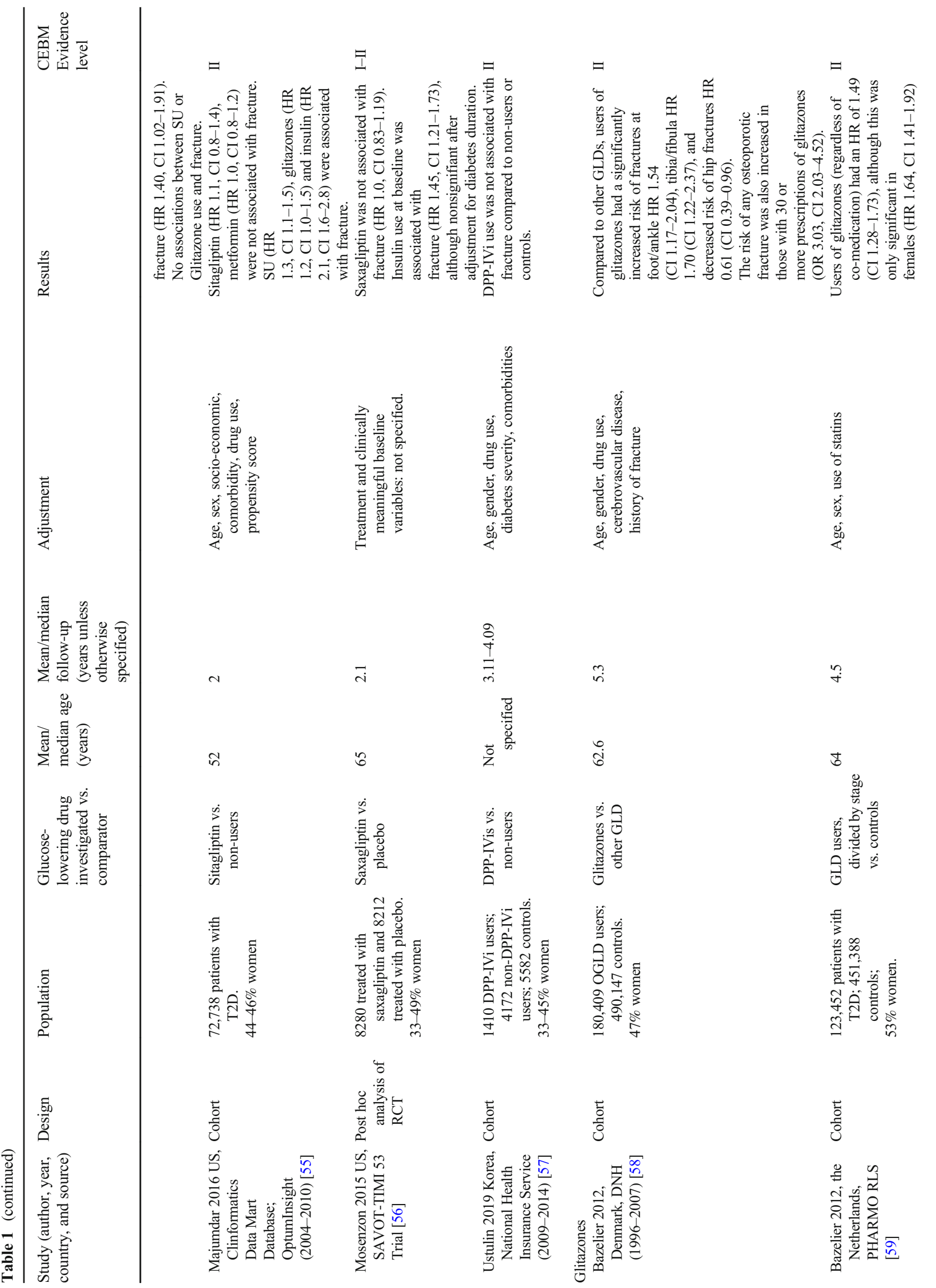




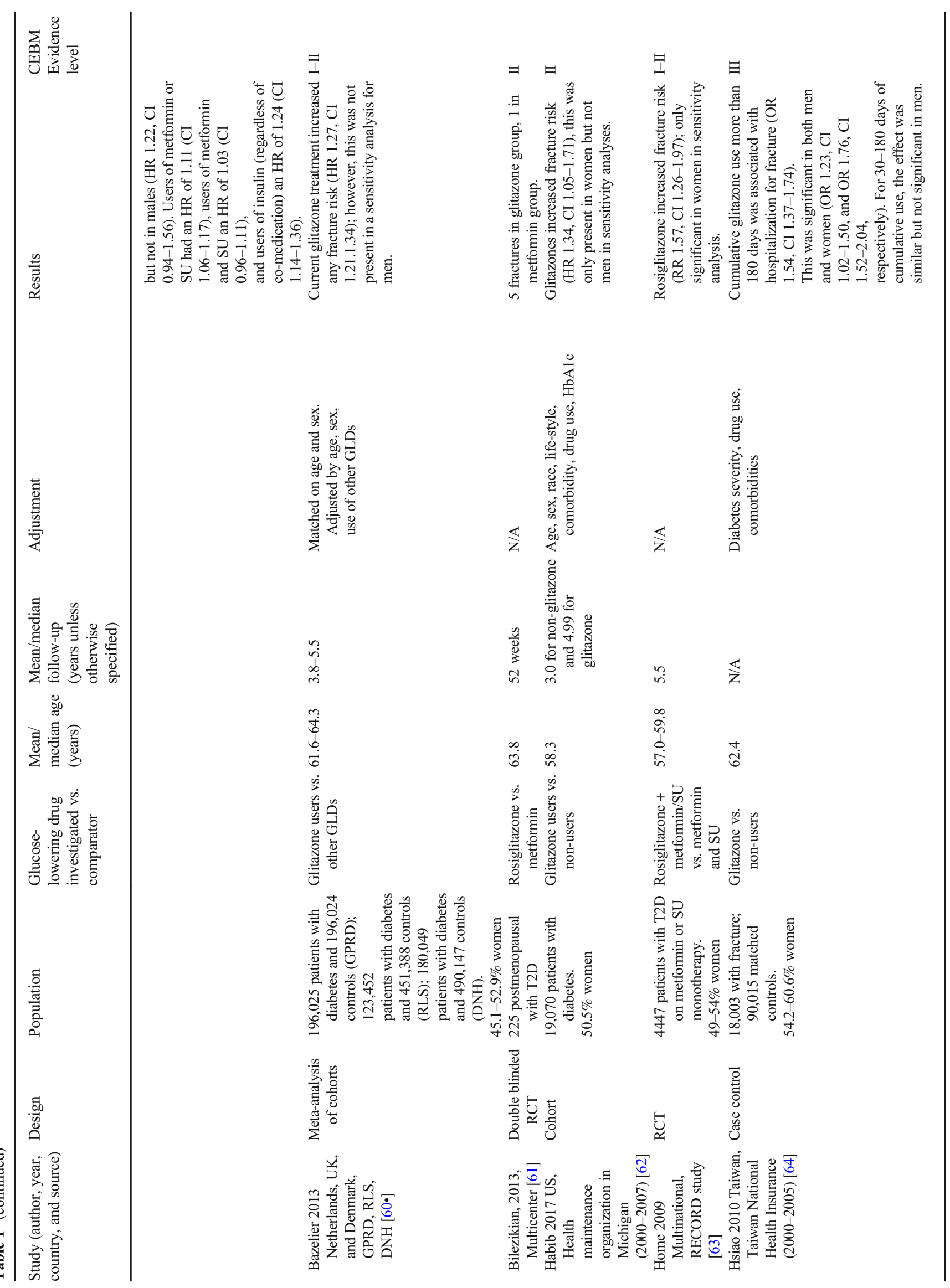




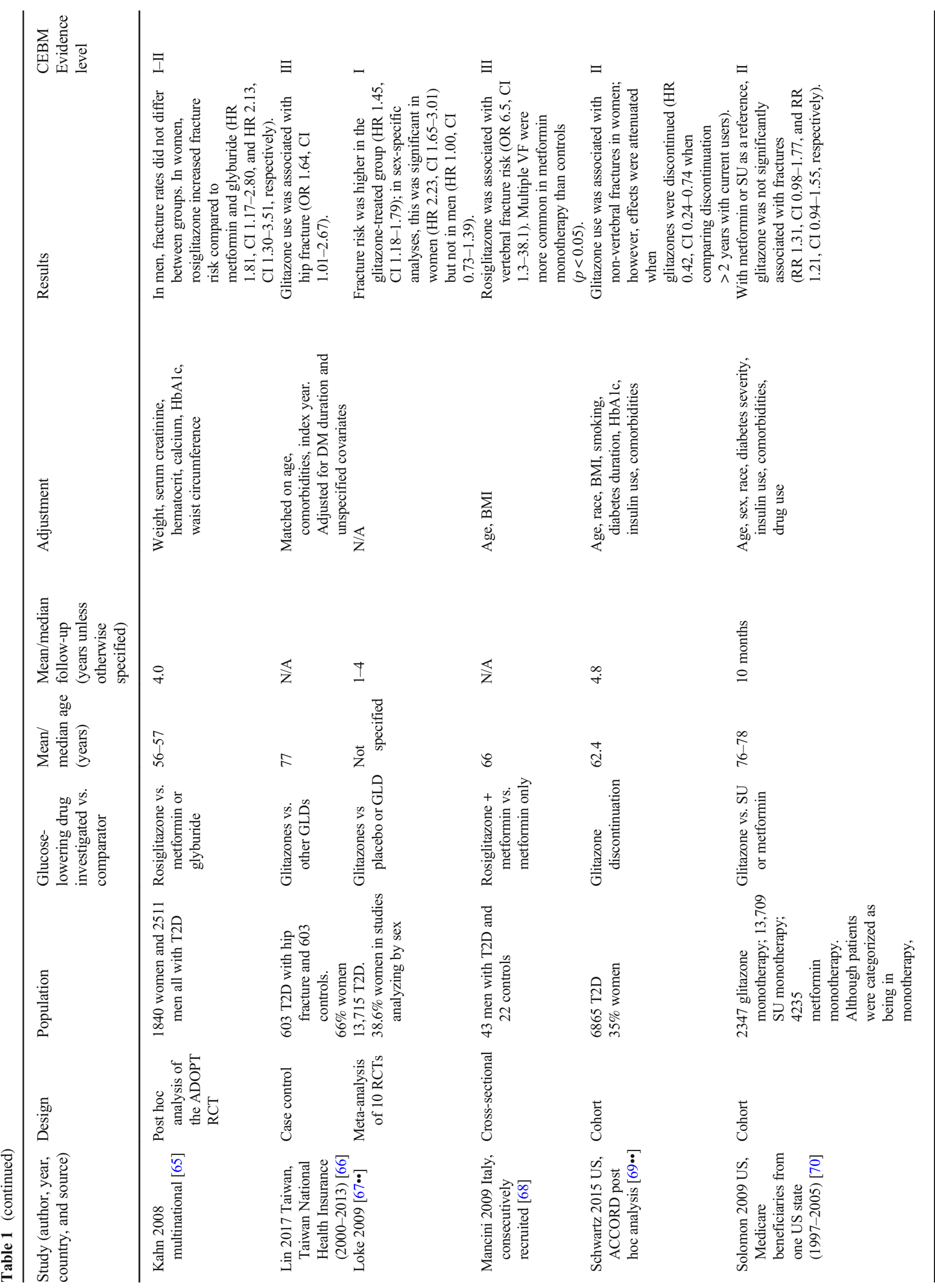




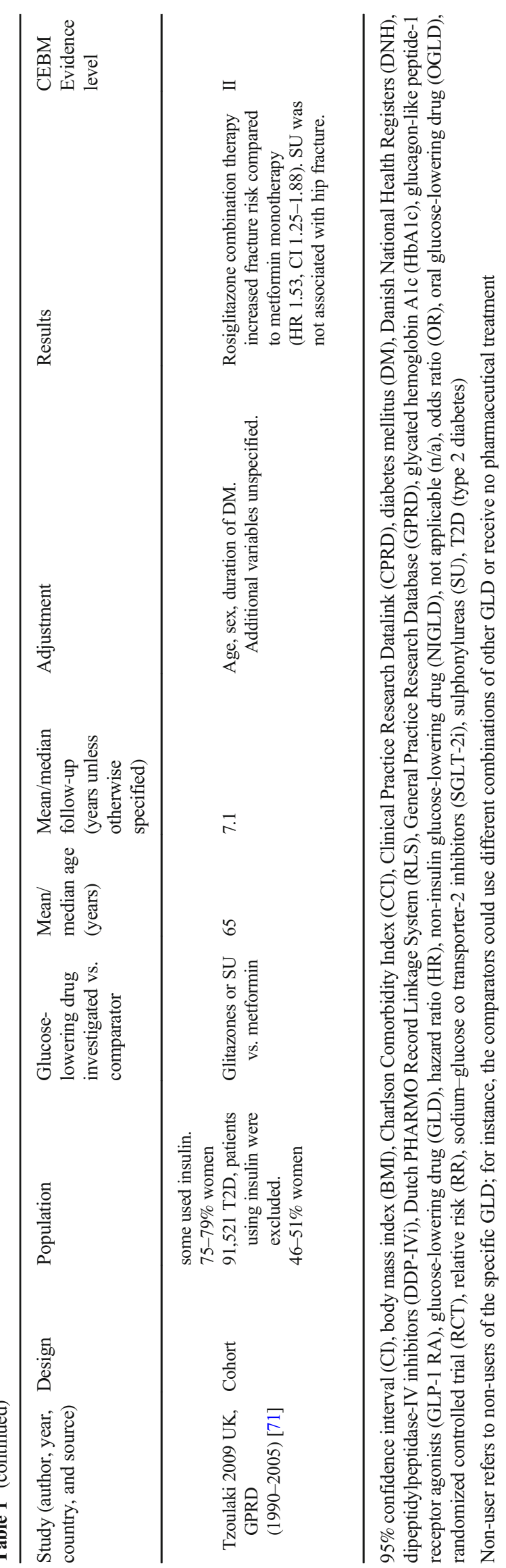


times, included patients by different criteria, and performed different comparisons and analyses, they were considered to be unique and eligible for inclusion. Two studies by Driessen and colleagues both used the Clinical Practice Research Datalink for the years 2007-2020 and 2007 with comparable populations investigating DPP-IVis and fracture. However, the study with the shortest follow-up duration presented additional analyses for insulin and glitazones and was thus included $[49,51]$.

In the following, the findings for each drug group are presented and discussed.

\section{Metformin}

Studies examining the effects of metformin were mainly observational studies. However, one RCT with a 4-year followup time reported a reduced risk of fractures in metformin users compared to rosiglitazone users [65]. Metformin monotherapy was associated with an increased fracture risk when compared to a non-diabetes population and a T2D population not using glucose-lowering drugs $[14,59]$. However, metformin was mainly associated with neutral outcomes $[13,15,20,24,55$, $59]$ or decreased fracture risk $[9,17,19,23,54 \cdot \bullet]$ in comparison to treatment with other glucose-lowering drugs. The interpretation of metformin in terms of fracture risk appears to depend on the comparator used. Based on the current evidence, metformin appears to be neutral in terms of fracture risk, although no final conclusions can be drawn.

\section{Sulphonylureas}

An RCT with a median treatment time of 4 years reported a reduced risk in glyburide users compared to rosiglitazone [65]. This RCT also compared rosiglitazone with metformin, and the fracture rates among metformin and glyburide users were similar, although not formally compared [65]. These findings seem to highlight the importance of the comparator used. Observational studies, however, have reported disparate effects of sulphonylureas. Some studies found sulphonylureas - as monotherapy or in combinations - to be associated with an increased fracture risk in comparison to other glucose-lowering drugs [14, 15, 18, 23, 32, 59], whereas other studies reported neutral effects on fracture outcomes [13, $18,20,24,59,60 \cdot 71]$. In two studies, sulphonylurea treatment was associated with a reduced risk of fracture $[9,16]$. Compared to non-sulphonylurea users, sulphonylurea use was associated with increased fracture risk in men with $\mathrm{HbAlc}<$ $6.5 \%$ [17]. To illustrate the divergence of findings between studies examining sulphonylureas: one propensity-matched study with new users of sulphonylureas and with metformin as the comparator reported no difference in fracture risk in T2D [26•], whereas another propensity-matched study where sulphonylureas were compared with other oral glucose- lowering drugs reported an increased hip fracture risk in patients using sulphonylureas [27]. These differences may reflect differences in the cohorts; the study by Lapane et al. included very mild diabetes (monotherapy) with a low risk of hypoglycemia, whereas the other study also included patients that were treated with multiple drugs [27]. A recent meta-analysis reported a $14 \%$ increased fracture risk in sulphonylurea users compared to T2D treated with different comparators [74]. Thus, the evidence on sulphonylureas is inconclusive.

\section{Glitazones}

A meta-analysis of ten RCTs reports increased fracture risk in female glitazone users compared to placebo or an active comparison $[67 \cdot \bullet]$. In addition, two RCTs showed that rosiglitazone was associated with a $57-81 \%$ increased fracture risk compared to metformin or sulphonylureas, the finding being significant only in women and not in men $[63,65]$. In observational studies, glitazones users had an increased fracture risk compared to non-glitazone users, users of metformin in monotherapy, users of other glucose-lowering drugs, or non-diabetics $[13,14,16,23,55,59,60 \bullet, 62,64,66,68$, 71]; however, in some studies which differentiated between men and women, the increased fracture risk was only present in women $[13,60 \bullet, 62,64]$. Furthermore, a study investigating discontinuation of glitazones reported that discontinuation significantly attenuates the fracture risk [69••]. However, glitazones were also associated with neutral outcomes in some studies compared to metformin monotherapy, sulphonylurea monotherapy, or other glucose-lowering drugs [18, 24, 70]; one such study reported a confidence interval from 0.98 to 1.77 [70], another study had only $32(0.2 \%)$ glitazone users [18], and a study had $0.1 \%$ glitazone users [24]. Although the RCTs have not been conducted with fracture as the primary outcome, the evidence is compelling that glitazones increase fracture risk in women, whereas it is more uncertain in men.

\section{Insulin}

In regard to fracture risk, several studies report that insulin use was associated with an increased fracture risk compared to other glucose-lowering drugs, non-insulin use, metformin monotherapy, or non-diabetics [15-22, 25, 31, 54••, 55, 59], but insulin use was also associated with neutral outcomes in other studies using similar comparators [9, 13, 24, 28, 32]. A study comparing women with T2D with non-diabetics reported that insulin users had an increased fracture risk, but so did non-insulin users [33]. A study investigating switch from oral glucose-lowering drugs to insulin found that this was associated with an increased fracture risk [29•0], and in a propensity score-matched study insulin users displayed an increased fracture risk compared to non-insulin users [30•]. The evidence on 
insulin use and fracture risk is difficult to decipher, as insulin therapy in T2D may be related to longer diabetes duration and severity, and epidemiologic studies may include T1D incorrectly classified as insulin using T2D, thereby overestimating fracture risk. Furthermore, some studies compare to a nondiabetic reference $[28,31,33]$, whereas others compare to other patients with diabetes $[18,29 \bullet \bullet, 32]$. Similarly to sulphonylureas, insulin use is associated with a risk of hypoglycemia. Insulin-treated patients with DM have a higher risk of low-impact falls [75], and under the assumption of frail bones this may lead to fractures. The combination of insulin and sulphonylureas was associated with a twofold increased risk of hip fracture [15], and insulin use was associated with increased fracture risk in men with $\mathrm{HbAlc}<6.5 \%$ [17]. Insulin use was associated with a reduced risk of fracture in one study [23]. Thus, physicians should be aware that the risk of hypoglycemia associated with insulin may lead to fractures.

\section{DPP-IV Inhibitors}

Most population-based observational studies reported no association between DPP-IVis and fracture, even in those with a treatment duration of 4 years or more compared to non-insulin glucose-lowering drugs or non-DDP-IVi use [49-52, 55, 57]. Neither in combination with metformin $[14,18]$ nor with insulin and metformin [18] could an association be found between DPP-IVi treatment and fracture when compared to metformin monotherapy or non-DPP-IVi use. However, DPPIVis were associated with a reduced risk of fracture in one study where they were compared to glitazones [52] and in two population-based studies compared to non-DPP-IVi use $[48,53]$, although one of these studies may be subject to immortal time bias [48]. In post hoc analyses of RCTs, DPP-IVi treatment was not associated with fracture compared to placebo $[54 \bullet \bullet, 56]$. In a meta-analysis of RCTs, DPP-IVi treatment was not associated with fractures compared to placebo or other glucose-lowering drugs [47]. However, the meta-analysis is limited by short follow-up durations (12 weeks to 43 months). In terms of fracture risk, treatment with DPP-IVi appears to be safe.

\section{GLP-1 Receptor Agonists}

GLP-1 RA treatment was associated with neutral fracture related outcomes in cohort studies [24, 43, 44]. In a metaanalysis of RCTs with follow-up durations between 26 weeks and 42 months, GLP-1 RA treatment was associated with a reduced fracture risk [42], whereas other meta-analyses of RCTs reported neutral results $[45,46]$. These meta-analyses are limited by short durations of follow-up (12 to 104 weeks). The current evidence, thus, points to neutral effects on fracture risk in patients with $\mathrm{T} 2 \mathrm{D}$.

\section{Sodium-Glucose Cotransporter 2 Inhibitors}

The current evidence from observational studies and RCTs is sparse and limited by short durations of follow-up. No difference in fracture risk was observed in two propensity scorematched cohort studies comparing new users of SGLT2-is with new users of GLP-1 RA $[35,40]$. In a propensity score-matched cohort study comparing new users of SGLT2-is with new users of DPP-IVi, an initial increase in fracture risk was observed in SGLT2-i users; however, this attenuated with longer treatment duration [34]. The finding is supported by a case-control study where combination treatment of metformin and SGLT2-is was not associated with fracture when compared to metformin and DPP-IVi in combination [38]. The initial fractures might be due to initial episodes of hypoglycemia in this study sample. However, users of insulin were excluded from the study, and SGLT2-is are in general considered safe in terms of hypoglycemia, wherefore we speculate this to be a chance finding. A meta-analysis of RCTs limited by short study durations (24-160 weeks) and a pooled analysis of 13 RCTs (of 12 or 24 weeks' duration) reported no increased fracture rate in SGLT2-i users compared to placebo or active treatment $[36,39 \cdot \bullet]$. Another metaanalysis of RCTs with at least 52 weeks of follow-up reported a $32 \%$ increased fracture risk compared to placebo or active treatment $[41 \bullet \cdot$. A post hoc analysis collating data from RCTs reported no increased fracture risk in SGLT2-i users compared to users of sulphonylureas or placebo [37]. Although the evidence in general supports no effect of SGLT2-is on fracture risk, the pooled analysis of data from RCTs reported an increased fracture risk in canagliflozine treated subjects [41••]. However, this study was compromised by short duration of treatment and of follow-up [41••].

\section{Discussion}

This systematic overview has presented data on the associations between glucose-lowering drugs and fracture risk. As highlighted, short study durations presented major limitations in both RCTs and meta-analyses, making assessment of fracture risk difficult. Fracture outcomes in studies with short durations (less than 1 year) would expectedly be due to falls and hypoglycemia, whereas long-term alterations of bone quality and structure expectedly evolve after a longer exposure. Although this review assesses several levels of evidence, the RCTs had limited study size in comparison to cohort studies. Observational studies, although examining larger population sizes, are subject to inherent bias, such as confounding by indication and comparison of dissimilar T2D populations. In addition, individuals with T1D may have been misclassified as having T2D in some studies, and registry data on medication are similarly subject to flaw. 
Metformin is the backbone of T2D treatment. In vitro studies suggest that metformin is bone anabolic by increasing osteoblastogenesis via increased Runx2 secretion [76]. However, in humans treatment with metformin for 12 months, treatment did not change $\mathrm{C}$-terminal cross-linked telopeptide of type-I collagen (CTX) levels, but bone specific alkaline phosphatase and pro-collagen type I N-terminal propeptide (P1NP) levels were reduced [77], and circulating metformin levels were not associated with CTX or P1NP levels [78].

The studies included in this review examining metformin were observational studies, and various comparators were used. Overall, the evidence points towards a neutral effect of metformin on fracture risk.

Sulphonylureas were found in an animal study to increase bone formation and inhibit changes caused by estrogen deficiency [79]. In humans, 12 months of glyburide treatment did not change CTX levels, and P1NP was slightly reduced, although to a lesser extent compared to metformin use [77]. Sulphonylureas are associated with hypoglycemic episodes [15], although a systematic review concluded that the evidence was too sparse to conclude that sulphonylureas increase risk of falls [80]. However, falls represent a plausible mechanism by which sulphonylurea-induced hypoglycemia may increase fracture risk. The findings regarding sulphonylureas in this review were more disparate, however, as some studies reported neutral outcomes, while others reported either increased or decreased fracture risk. These seemingly contrasting findings may be due to differences between studies, as there appears to be a difference between individuals in monotherapy and individuals treated with multiple glucoselowering drugs. However, it is worth considering whether the increased risk of hypoglycemia is associated with an increased fracture risk mediated by falls in individuals with strict glycemic control or concomitant use of insulin.

Glitazones are the glucose-lowering drugs with the most evidence on bone health and fracture risk. Glitazones cause differentiation of mesenchymal stem cells into an adipocytic lineage instead of an osteoblastic lineage [81]. Humans treated with glitazones have demonstrated increased CTX levels, reduced P1NP levels [77], and lower BMD [67••].

Glitazones were well-examined compared to the other glucose-lowering drugs, and the evidence points more clearly towards an increased fracture risk in women, whereas the evidence is less definitive in men. Thus, caution should be taken when prescribing glitazones to women.

Insulin is suggested to be bone anabolic [82]. In a murine model of type 1 diabetes, treatment with insulin led to significantly less bone loss [83]. Thus, insulin and addition of exogenous insulin may improve bone mass. However, a study reported no acute changes in bone turnover markers at different insulin levels in both non-diabetic subjects and patients with T2D [84]. The type of insulin seems to be of no consequence, as CTX and P1NP increased similarly in both groups after randomization to 2 years of treatment with short-acting insulin (aspart) or long-acting insulin (NPH, neutral protamine Hagedorn) [78]. With regard to fracture risk, insulin treatment was associated with varying findings, although several studies reported increased fracture risk. This may be related to misclassification of T1D as T2D and may also be related to more severe diabetes in individuals receiving insulin than in noninsulin users. However, the risk of hypoglycemia associated with insulin use may be a cause of falls and fractures.

Hypoglycemia is an unwanted side effect of both insulin and SUs. If these drugs can be administered without causing hypoglycemia and fall risk, it may be possible to avoid an increased risk of fractures.

In vitro studies have suggested that DPP-IVis influence bone metabolism by prolonging the effects of gastric inhibitory peptide (GIP) [85], and in T1D patients GIP infusion decreased CTX levels independently of glycemia [86]. Also, sitagliptin inhibited bone resorption in vitro [87].

In almost all studies, DDP-IVis were not associated with fracture risk, suggesting that DPP-IVi treatment is probably safe with regard to fracture, although most studies were observational and intervention studies were limited by short follow-up.

Thus, the evidence suggests that DPP-IVis are safe in terms of fracture risk, albeit with no protective effect.

GLP-1 RA constitutes a relatively new glucose-lowering drug group which has cardioprotective effects [88]. Osteoblastic cell lines express GLP-1 receptors, and GLP-1 increases osteoblastic differentiation and proliferation [89] and GLP-1 receptor knockout mice had an increased number of osteoblasts and reduced bone mass [90]. In an RCT on patients with T2D, liraglutide treatment for 26 weeks did not alter CTX or P1NP despite weight loss and preserved hip BMD compared to the placebo group [91]. Additionally, in obese subjects undergoing weight loss by caloric restriction liraglutide prevented bone loss and increased P1NP compared to controls [92]. Although the preclinical and clinical evidence points to potential beneficial effects of GLP-1 RAs on bone, GLP-1 RAs were not associated with fracture risk in the presented studies. However, it is worth considering whether GLP-1 RAs may protect bones during weight loss, which is associated with frailty fractures in T2D [93]. It is expected that the numbers treated with GLP-1 RAs will increase due to the cardioprotective effect. Thus, it is important to observe potential side effects such as fracture in the coming years.

SGLT2-is are also a relatively new group of glucoselowering drugs with both cardioprotective and renoprotective effects $[94,95]$. In terms of bone health, it was hypothesized that the glucosuria seen in SGLT2-i treatment would cause an osmotic loss of minerals and thereby bone loss. Diabetic mice treated with SGLT2-is had impaired cortical and trabecular bone microarchitecture and increased CTX levels compared with non-treated animals [96]; however, not all animal studies 
found detrimental effects of SGLT2-is [97]. In older patients with T2D, levels of CTX and P1NP increased and a small yet significant bone loss was observed in canagliflozin-treated patients with T2D compared with placebo-treated patients with T2D [98]. Thus, it is unclear whether SGLT2-is have a negative effect on bone health. However, it is also worth considering whether SGLT2-is has an indirect effect on fracture risk by inducing weight loss [99].

SGLT2-is was not associated with fracture risk in most of the included studies, although a pooled analysis of data from RCTs with 1-2 years of follow-up did report an increased fracture risk. There may be differential effects among SGLT2-is as Watts et al. found canagliflozine to be associated with an increased risk of adjudicated fractures with a HR of $1.32(95 \%$ CI $1.00-1.74)[41 \bullet \cdot]$ and the meta-analysis by Tang et al. reported a pooled OR of 1.24 (95\% CI $0.79-$ 1.95) [39••]. Although non-significant, the meta-analysis by Tang et al. is suggestive of an increased fracture risk in canagliflozine users. In contrast, neither dapagliflozine nor empagliflozine were associated with fracture risk in the pooled analyses $[36,37,39 \bullet \cdot]$. Thus, future studies should examine possible differential effects of SGLT2-is. As more patients will be treated with these drugs and current studies have relatively short follow-up periods, it is important to follow potential fractures in SGLT2-i and GLP-1 RA-treated individuals and patients undergoing intended weight loss.

Metformin is an insulin sensitizer, and SGLT2-i and GLP1 RA both cause a mild to moderate weight loss; thus, these drugs are commonly used in obese T2D subjects. Metformin, SGLT2-is, and GLP-1 RAs all appear to be neutral in terms of fracture risk; however, this may be partly due to confounding by indication in observational studies; as increasing BMI is associated with increased BMD and obesity itself is associated with reduced fracture risk [100], although debated as abdominal obesity has been associated with fractures [101]. In addition, obese individuals may be less prone to hypoglycemia due to insulin resistance.

The uncertainty in interpreting the results of studies on fracture risk and glucose-lowering drug use is emphasized by the fact that while studies have found increased fracture risk in individuals with T2D $[1 \bullet \bullet$, some studies have found the effect to be fully attenuated after adjusting for insulin use [25, 102]. Fracture risk may, for instance, be elevated in certain diabetic populations due to a variety of factors influencing fall risk in addition to hypoglycemia. Apart from age being a risk factor for falls [103], diabetes itself is associated with an increased risk of falls [104] at least in part due to polypharmacy, poor walking function (including affected posture and gait), and reduced cognitive function [105, 106]. Gait performance may be affected by complications to diabetes, such as diabetic sensory neuropathy [107], diabetic retinopathy [108], or reduced muscle strength [109]. In addition, concomitant drug use (e.g., antihypertensive drugs) and comorbidities (e.g., dizziness and cardiovascular disease) increase fall risk [110].

Finally, a general concern with registry studies is underreporting; both fracture rates and T2DM prevalence may be subject to error, leading to underestimation of associations.

\section{Conclusion}

Metformin, dipeptidylpeptidase-IV inhibitors, glucagon-like peptide-1 receptor agonists, and sodium-glucose cotransporter 2-inhibitors appear to be safe with regard to fracture risk. Results for insulin and sulphonylureas were more disparate, although there may be an increased fracture risk related to hypoglycemia and falls with these treatments. Glitazones were consistently associated with increased fracture risk in women, although the evidence was sparser in men.

When prescribing glucose-lowering drugs, particularly to the elderly osteoporosis-prone population, care must be given in determining the right drug to prescribe, and fracture risk should be considered in this assessment. In particular, it is worth noting the introduction of new glucose-lowering drugs and changes in possible prescription patterns.

It is important to gain a better understanding of the effects of different glucose-lowering drugs on fracture risk, as fractures lead to higher morbidity and mortality, and evidently more so in the diabetic population [111]. Therefore, our findings warrant continued research on the effects of glucoselowering drugs on fracture risk, elucidating the class-specific effects of these drugs.

Funding This work has received funding by Steno Collaborative grant, Novo Nordisk Foundation Denmark (Grant no. NNF18OC0052064).

\section{Compliance with Ethical Standards}

Zheer Al-Mashhadi and Jakob Starup-Linde drafted the manuscript, conducted the systematic literature search contributed to the interpretation of data, critical editing of written text, and approved the final version of the manuscript. Rikke Viggers, Rasmus Fuglsang-Nielsen, Frank de Vries, Joop van den Bergh, Torben Harsløf, Bente Langdahl, and Søren Gregersen contributed to the interpretation of data, critical editing of written text, and approved the final version of the manuscript.

Conflict of Interest Z Al-Mashhadi, R Viggers, R Fuglsang-Nielsen, JP van den Bergh, T Harsløf and S Gregersen declare no conflict of interest.

J. Starup-Linde reports personal fees from GSK Pharma A/S and Gilead Sciences Denmark, outside the submitted work.

F. de Vries supervises three PhD students who are currently employed with F. Hoffmann La Roche Ltd. (Welwyn Garden City UK and Basel, Switzerland). The topics of their PhDs do not relate to the current study. Dr. de Vries has not received any fees or reimbursements for this.

JP van den Bergh reports grants from Amgen, UCB and Eli-Lilly and personal fees from UCB and Amgen outside the submitted work. 
B. Langdahl reports grants from Amgen, grants from Novo Nordisk, personal fees from Amgen, personal fees from UCB, personal fees from Gedeon-Richter, personal fees from Gilead, outside the submitted work.

Human and Animal Rights and Informed Consent This article does not contain any studies with human or animal subjects performed by any of the authors.

\section{References}

Papers of particular interest, published recently, have been highlighted as:

- Of importance

- Of major importance

1.• Vestergaard P. Discrepancies in bone mineral density and fracture risk in patients with type 1 and type 2 diabetes-a meta-analysis. Osteoporos Int. 2007;18(4):427-44 This meta-analysis revealed both an increased fracture risk in patients with diabetes, but also that bone mineral density does not explain the fracture risk.

2. Farr JN, Drake MT, Amin S, Melton IL, McCready LK, Khosla S. In vivo assessment of bone quality in postmenopausal women with type 2 diabetes. J Bone Miner Res. 2014;29(4):787-95.

3. Saito M, Kida Y, Kato S, Marumo K. Diabetes, collagen, and bone quality. Curr Osteoporosis Rep. 2014;12(2):181-8.

4. Hygum K, Starup-Linde J, Harslof T, Vestergaard P, Langdahl BL. MECHANISMS IN ENDOCRINOLOGY: diabetes mellitus, a state of low bone turnover - a systematic review and meta-analysis. Eur J Endocrinol. 2017;176(3):R137-57.

5. Vestergaard P, Rejnmark L, Mosekilde L. Diabetes and its complications and their relationship with risk of fractures in type 1 and 2 diabetes. Calcif Tissue Int. 2009;84(1):45-55.

6. Majumdar SR, Leslie WD, Lix LM, Morin SN, Johansson H, Oden A, et al. Longer duration of diabetes strongly impacts fracture risk assessment: the Manitoba BMD cohort. J Clin Endocrinol Metab. 2016;101(11):4489-96.

7. Hygum K, Starup-Linde J, Langdahl BL. Diabetes and bone. Osteoporos Sarcopenia. 2019;5(2):29-37. https://doi.org/10. 1016/j.afos.2019.05.001.

8. Yokomoto-Umakoshi M, Kanazawa I, Kondo S, Sugimoto T. Association between the risk of falls and osteoporotic fractures in patients with type 2 diabetes mellitus. Endocr J. 2017;64(7): 727-34.

9. Vestergaard P, Rejnmark L, Mosekilde L. Relative fracture risk in patients with diabetes mellitus, and the impact of insulin and oral antidiabetic medication on relative fracture risk. Diabetologia. 2005;48(7):1292-9.

10. Buse JB, Wexler DJ, Tsapas A, Rossing P, Mingrone G, Mathieu C, et al. 2019 update to: management of hyperglycaemia in type 2 diabetes, 2018. A consensus report by the American Diabetes Association (ADA) and the European Association for the Study of Diabetes (EASD). Diabetologia. 2020;63(2):221-8.

11. Liberati A, Altman DG, Tetzlaff J, Mulrow C, Gotzsche PC, Ioannidis JP, et al. The PRISMA statement for reporting systematic reviews and meta-analyses of studies that evaluate healthcare interventions: explanation and elaboration. BMJ. 2009;339: b2700.

12. Available at: https://www.cebm.net/2009/06/oxford-centreevidence-based-medicine-levels-evidence-march-2009/. Accessed 03/30, 2020.
13. Chen HH, Horng MH, Yeh SY, Lin IC, Yeh CJ, Muo CH, et al. Glycemic control with thiazolidinedione is associated with fracture of T2DM patients. PLoS One. 2015;10(8):e0135530.

14. Choi HJ, Park C, Lee YK, Ha YC, Jang S, Shin CS. Risk of fractures and diabetes medications: a nationwide cohort study. Osteoporos Int. 2016;27(9):2709-15. https://doi.org/10.1007/ s00198-016-3595-6.

15. Hung YC, Lin CC, Chen HJ, Chang MP, Huang KC, Chen YH, et al. Severe hypoglycemia and hip fracture in patients with type 2 diabetes: a nationwide population-based cohort study. Osteoporos Int. 2017;28(7):2053-60.

16. Kanazawa I, Yamaguchi $T$, Yamamoto $M$, Sugimoto $T$. Relationship between treatments with insulin and oral hypoglycemic agents versus the presence of vertebral fractures in type 2 diabetes mellitus. J Bone Miner Metab. 2010;28(5):554-60.

17. Lee RH, Sloane R, Pieper C, Lyles KW, Adler RA, Van Houtven $\mathrm{C}$, et al. Glycemic control and insulin treatment alter fracture risk in older men with type 2 diabetes mellitus. J Bone Miner Res. 2019;34(11):2045-51.

18. Losada E, Soldevila B, Ali MS, Martínez-Laguna D, Nogués X, Puig-Domingo M, Díez-Pérez A, Mauricio D, Prieto-Alhambra D. Real-world antidiabetic drug use and fracture risk in 12,277 patients with type 2 diabetes mellitus: a nested case-control study. Osteoporos Int. 2018;29(9):2079-86. https://doi.org/10.1007/ s00198-018-4581-y.

19. Melton LJ 3rd, Leibson CL, Achenbach SJ, Therneau TM, Khosla S. Fracture risk in type 2 diabetes: update of a population-based study. J Bone Miner Res. 2008;23(8):1334-42.

20. Monami M, Cresci B, Colombini A, Pala L, Balzi D, Gori F, et al. Bone fractures and hypoglycemic treatment in type 2 diabetic patients: a case-control study. Diabetes Care. 2008;31(2):199-203.

21. Nicodemus KK, Folsom AR, Iowa Women's Health Study. Type 1 and type 2 diabetes and incident hip fractures in postmenopausal women. Diabetes Care. 2001;24(7):1192-7.

22. Schneider AL, Williams EK, Brancati FL, Blecker S, Coresh J, Selvin E. Diabetes and risk of fracture-related hospitalization: the Atherosclerosis Risk in Communities Study. Diabetes Care. 2013;36(5):1153-8.

23. Starup-Linde J, Gregersen S, Frost M, Vestergaard P. Use of glucose-lowering drugs and risk of fracture in patients with type 2 diabetes. Bone. 2017;95:136-42.

24. Starup-Linde J, Gregersen S, Vestergaard P. Associations with fracture in patients with diabetes: a nested case-control study. BMJ Open. 2016;6(2):e009686 -2015-009686.

25. Wallander M, Axelsson KF, Nilsson AG, Lundh D, Lorentzon M. Type 2 diabetes and risk of hip fractures and non-skeletal fall injuries in the elderly: a Study from the fractures and fall injuries in the elderly cohort (FRAILCO). J Bone Miner Res. 2017;32(3): 449-60.

26. Lapane KL, Jesdale BM, Dube CE, Pimentel CB, Rajpathak SN. Sulfonylureas and risk of falls and fractures among nursing home residents with type 2 diabetes mellitus. Diabetes Res Clin Pract. 2015;109(2):411-9 Nursing home residents were at an increased risk of falls when initiating sulphonylureas.

27. Rajpathak SN, Fu C, Brodovicz KG, Engel SS, Lapane K. Sulfonylurea use and risk of hip fractures among elderly men and women with type 2 diabetes. Drugs Aging. 2015;32(4):321-7.

28. Ahmed LA, Joakimsen RM, Berntsen GK, Fonnebo V, Schirmer H. Diabetes mellitus and the risk of non-vertebral fractures: the Tromso study. Osteoporos Int. 2006;17(4):495-500.

29.• Corrao G, Monzio Compagnoni M, Ronco R, Merlino L, Ciardullo S, Perseghin G, Banfi G. Is Switching from Oral Antidiabetic Therapy to Insulin Associated with an Increased Fracture Risk? Clin Orthop Relat Res. 2020;478(5):992-1003. https://doi.org/10.1097/CORR.0000000000001089. Switch to insulin was associated with an increased fracture risk. 
30. Losada-Grande E, Hawley S, Soldevila B, Martinez-Laguna D, Nogues X, Diez-Perez A, et al. Insulin use and excess fracture risk in patients with type 2 diabetes: a propensity-matched cohort analysis. Sci Rep. 2017;7(1):3781 -017-03748-z. In a propensitymatched analysis, insulin use was associated with an increased fracture risk.

31. Ottenbacher KJ, Ostir GV, Peek MK, Goodwin JS, Markides KS. Diabetes mellitus as a risk factor for hip fracture in Mexican American older adults. J Gerontol A Biol Sci Med Sci. 2002;57(10):M648-53.

32. Pscherer S, Kostev K, Dippel FW, Rathmann W. Fracture risk in patients with type 2 diabetes under different antidiabetic treatment regimens: a retrospective database analysis in primary care. Diabetes Metab Syndr Obes. 2016;9:17-23.

33. Schwartz AV, Sellmeyer DE, Ensrud KE, Cauley JA, Tabor HK, Schreiner PJ, et al. Older women with diabetes have an increased risk of fracture: a prospective study. J Clin Endocrinol Metab. 2001;86(1):32-8.

34. Adimadhyam S, Lee TA, Calip GS, Smith Marsh DE, Layden BT, Schumock GT. Sodium-glucose co-transporter 2 inhibitors and the risk of fractures: a propensity score-matched cohort study. Pharmacoepidemiol Drug Saf. 2019;28(12):1629-39.

35. Fralick M, Kim SC, Schneeweiss S, Kim D, Redelmeier DA, Patorno E. Fracture risk after initiation of use of canagliflozin: a cohort study. Ann Intern Med. 2019;170(3):155-63.

36. Jabbour S, Seufert J, Scheen A, Bailey CJ, Karup C, Langkilde AM. Dapagliflozin in patients with type 2 diabetes mellitus: a pooled analysis of safety data from phase IIb/III clinical trials. Diabetes Obes Metab. 2018;20(3):620-8.

37. Kohler S, Kaspers S, Salsali A, Zeller C, Woerle HJ. Analysis of fractures in patients with type 2 diabetes treated with empagliflozin in pooled data from placebo-controlled trials and a head-to-head study versus glimepiride. Diabetes Care. 2018;41(8):1809-16. https://doi.org/10.2337/dc17-1525.

38. Schmedt N, Andersohn F, Walker J, Garbe E. Sodium-glucose cotransporter-2 inhibitors and the risk of fractures of the upper or lower limbs in patients with type 2 diabetes: a nested case-control study. Diabetes Obes Metab. 2019;21(1):52-60.

39.• Tang HL, Li DD, Zhang JJ, Hsu YH, Wang TS, Zhai SD, et al. Lack of evidence for a harmful effect of sodium-glucose co-transporter 2 (SGLT2) inhibitors on fracture risk among type 2 diabetes patients: a network and cumulative meta-analysis of randomized controlled trials. Diabetes Obes Metab. 2016;18(12):1199-206 In this meta-analysis of randomized controlled trials SGLT-2is were not associated with an increased risk of fracture.

40. Ueda P, Svanstrom H, Melbye M, Eliasson B, Svensson AM, Franzen S, et al. Sodium glucose cotransporter 2 inhibitors and risk of serious adverse events: nationwide register based cohort study. BMJ. 2018;363:k4365.

41.• Watts NB, Bilezikian JP, Usiskin K, Edwards R, Desai M, Law G, et al. Effects of canagliflozin on fracture risk in patients with type 2 diabetes mellitus. J Clin Endocrinol Metab. 2016;101(1):157-66 In this meta-analysis of randomized controlled trials canagliflozin was associated with an increased risk of fracture.

42. Cheng L, Hu Y, Li YY, Cao X, Bai N, Lu TT, et al. Glucagon-like peptide-1 receptor agonists and risk of bone fracture in patients with type 2 diabetes: a meta-analysis of randomized controlled trials. Diabetes Metab Res Rev. 2019;35(7):e3168.

43. Driessen JH, Henry RM, van Onzenoort HA, Lalmohamed A, Burden AM, Prieto-Alhambra D, et al. Bone fracture risk is not associated with the use of glucagon-like peptide-1 receptor agonists: a population-based cohort analysis. Calcif Tissue Int. 2015;97(2):104-12.

44. Driessen JH, van Onzenoort HA, Starup-Linde J, Henry R, Burden AM, Neef C, van den Bergh JP, Vestergaard P, de Vries F. Use of glucagon-like-peptide 1 receptor agonists and risk of fracture as compared to use of other anti-hyperglycemic drugs. Calcif Tissue Int. 2015;97(5):506-15. https://doi.org/10.1007/ s00223-015-0037-y.

45. Mabilleau G, Mieczkowska A, Chappard D. Use of glucagon-like peptide-1 receptor agonists and bone fractures: a meta-analysis of randomized clinical trials. J Diabetes. 2014;6(3):260-6.

46. Su B, Sheng H, Zhang M, Bu L, Yang P, Li L, et al. Risk of bone fractures associated with glucagon-like peptide-1 receptor agonists' treatment: a meta-analysis of randomized controlled trials. Endocrine. 2015;48(1):107-15.

47. Chen Q, Liu T, Zhou H, Peng H, Yan C. Risk of fractures associated with dipeptidyl peptidase-4 inhibitor treatment: a systematic review and meta-analysis of randomized controlled trials. Diabetes Ther. 2019;10(5):1879-92.

48. Dombrowski S, Kostev K, Jacob L. Use of dipeptidyl peptidase-4 inhibitors and risk of bone fracture in patients with type 2 diabetes in Germany-a retrospective analysis of real-world data. Osteoporos Int. 2017;28(8):2421-8.

49. Driessen JH, van Onzenoort HA, Henry RM, Lalmohamed A, van den Bergh JP, Neef C, et al. Use of dipeptidyl peptidase-4 inhibitors for type 2 diabetes mellitus and risk of fracture. Bone. 2014;68:124-30.

50. Driessen JH, van Onzenoort HA, Starup-Linde J, Henry R, Neef C, van den Bergh J, et al. Use of dipeptidyl peptidase 4 inhibitors and fracture risk compared to use of other anti-hyperglycemic drugs. Pharmacoepidemiol Drug Saf. 2015;24(10):1017-25.

51. Driessen JH, van den Bergh JP, van Onzenoort HA, Henry RM, Leufkens HG, de Vries F. Long-term use of dipeptidyl peptidase-4 inhibitors and risk of fracture: a retrospective population-based cohort study. Diabetes Obes Metab. 2017;19(3):421-8.

52. Gamble JM, Donnan JR, Chibrikov E, Twells LK, Midodzi WK, Majumdar SR. The risk of fragility fractures in new users of dipeptidyl peptidase-4 inhibitors compared to sulfonylureas and other anti-diabetic drugs: a cohort study. Diabetes Res Clin Pract. 2018;136:159-67.

53. Hou WH, Chang KC, Li CY, Ou HT. Dipeptidyl peptidase-4 inhibitor use is associated with decreased risk of fracture in patients with type 2 diabetes: a population-based cohort study. Br J Clin Pharmacol. 2018;84(9):2029-39.

54.• Josse RG, Majumdar SR, Zheng Y, Adler A, Bethel MA, Buse JB, et al. Sitagliptin and risk of fractures in type 2 diabetes: results from the TECOS trial. Diabetes Obes Metab. 2017;19(1):78-86 This randomized controlled trial report no difference in fracture rates between sitagliptin and placebo users.

55. Majumdar SR, Josse RG, Lin M, Eurich DT. Does sitagliptin affect the rate of osteoporotic fractures in type 2 diabetes? Population-based cohort study. J Clin Endocrinol Metab. 2016;101(5):1963-9.

56. Mosenzon O, Wei C, Davidson J, Scirica BM, Yanuv I, Rozenberg A, et al. Incidence of fractures in patients with type 2 diabetes in the SAVOR-TIMI 53 trial. Diabetes Care. 2015;38(11):2142-50.

57. Ustulin M, Park SY, Choi H, Chon S, Woo JT, Rhee SY. Effect of dipeptidyl peptidase-4 inhibitors on the risk of bone fractures in a Korean population. J Korean Med Sci. 2019;34(35):e224.

58. Bazelier MT, Vestergaard P, Gallagher AM, van Staa TP, Cooper C, Leufkens HG, et al. Risk of fracture with thiazolidinediones: disease or drugs? Calcif Tissue Int. 2012;90(6):450-7.

59. Bazelier MT, Gallagher AM, van Staa TP, Cooper C, Leufkens $\mathrm{HG}$, Vestergaard P, et al. Use of thiazolidinediones and risk of osteoporotic fracture: disease or drugs? Pharmacoepidemiol Drug Saf. 2012;21(5):507-14.

60. Bazelier MT, de Vries F, Vestergaard P, Herings RM, Gallagher AM, Leufkens HG, van Staa TP. Risk of fracture with thiazolidinediones: an individual patient data meta-analysis. Front Endocrinol (Lausanne). 2013;4:11. https://doi.org/10.3389/ 
fendo.2013.00011. This large analysis of three population report increased fracture risk with current glitazone use in women.

61. Bilezikian JP, Josse RG, Eastell R, Lewiecki EM, Miller CG, Wooddell M, et al. Rosiglitazone decreases bone mineral density and increases bone turnover in postmenopausal women with type 2 diabetes mellitus. J Clin Endocrinol Metab. 2013;98(4):1519-28.

62. Habib ZA, Havstad SL, Wells K, Divine G, Pladevall M, Williams LK. Thiazolidinedione use and the longitudinal risk of fractures in patients with type 2 diabetes mellitus. J Clin Endocrinol Metab. 2010;95(2):592-600.

63. Home PD, Pocock SJ, Beck-Nielsen H, Curtis PS, Gomis R, Hanefeld M, et al. Rosiglitazone evaluated for cardiovascular outcomes in oral agent combination therapy for type 2 diabetes (RECORD): a multicentre, randomised, open-label trial. Lancet. 2009;373(9681):2125-35.

64. Hsiao FY, Mullins CD. The association between thiazolidinediones and hospitalisation for fracture in type 2 diabetic patients: a Taiwanese population-based nested case-control study. Diabetologia. 2010;53(3):489-96.

65. Kahn SE, Zinman B, Lachin JM, Haffner SM, Herman WH, Holman RR, et al. Rosiglitazone-associated fractures in type 2 diabetes: an Analysis from A Diabetes Outcome Progression Trial (ADOPT). Diabetes Care. 2008;31(5):845-51.

66. Lin HF, Liao KF, Chang CM, Lin CL, Lin CH, Lai SW. Use of thiazolidinediones and risk of hip fracture in old people in a casecontrol study in Taiwan. Medicine (Baltimore). 2017;96(36): e7712.

67.•• Loke YK, Singh S, Furberg CD. Long-term use of thiazolidinediones and fractures in type 2 diabetes: a meta-analysis. CMAJ. 2009;180(1): 32-9 This meta-analysis reports increased fracture risk among glitazone users.

68. Mancini T, Mazziotti G, Doga M, Carpinteri R, Simetovic N, Vescovi PP, et al. Vertebral fractures in males with type 2 diabetes treated with rosiglitazone. Bone. 2009;45(4):784-8.

69.• Schwartz AV, Chen H, Ambrosius WT, Sood A, Josse RG, Bonds DE, et al. Effects of TZD use and discontinuation on fracture rates in ACCORD bone tudy. J Clin Endocrinol Metab. 2015;100(11): 4059-66 Discontinuation of glitazone use in women attenuated the increased fracture risk.

70. Solomon DH, Cadarette SM, Choudhry NK, Canning C, Levin R, Sturmer T. A cohort study of thiazolidinediones and fractures in older adults with diabetes. J Clin Endocrinol Metab. 2009;94(8): 2792-8.

71. Tzoulaki I, Molokhia M, Curcin V, Little MP, Millett CJ, Ng A, et al. Risk of cardiovascular disease and all cause mortality among patients with type 2 diabetes prescribed oral antidiabetes drugs: retrospective cohort study using UK general practice research database. BMJ. 2009;339:b4731.

72. Kostev K, Dombrowski S. Fracture risk reduction with use of dipeptidyl peptidase-4 inhibitors: response to Driessen et al. Osteoporos Int. 2017;28(8):2431.

73. Patorno E, Patrick AR, Garry EM, Schneeweiss S, Gillet VG, Bartels DB, et al. Observational studies of the association between glucose-lowering medications and cardiovascular outcomes: addressing methodological limitations. Diabetologia. 2014;57(11): 2237-50.

74. Zhang Z, Cao Y, Tao Y, Meng E, Tang J, Liu Y, et al. Sulfonylurea and fracture risk in patients with type 2 diabetes mellitus: a meta-analysis. Diabetes Res Clin Pract. 2020;159: 107990.

75. Kennedy RL, Henry J, Chapman AJ, Nayar R, Grant P, Morris $\mathrm{AD}$. Accidents in patients with insulin-treated diabetes: increased risk of low-impact falls but not motor vehicle crashes-a prospective register-based study. J Trauma. 2002;52(4):660-6.
76. Molinuevo MS, Schurman L, McCarthy AD, Cortizo AM, Tolosa MJ, Gangoiti MV, et al. Effect of metformin on bone marrow progenitor cell differentiation: in vivo and in vitro studies. $\mathrm{J}$ Bone Miner Res. 2010;25(2):211-21.

77. Zinman B, Haffner SM, Herman WH, Holman RR, Lachin JM, Kravitz BG, et al. Effect of rosiglitazone, metformin, and glyburide on bone biomarkers in patients with type 2 diabetes. J Clin Endocrinol Metab. 2010;95(1):134-42.

78. Beck-Nielsen H, Stage TB, Christensen MH, Jorgensen NR, Brosen K, Gram J, et al. Effects of metformin, rosiglitazone and insulin on bone metabolism in patients with type 2 diabetes. Bone. 2018;112:35-41.

79. Fronczek-Sokol J, Pytlik M. Effect of glimepiride on the skeletal system of ovariectomized and non-ovariectomized rats. Pharmacol Rep. 2014;66(3):412-7.

80. Lapane KL, Yang S, Brown MJ, Jawahar R, Pagliasotti C, Rajpathak S. Sulfonylureas and risk of falls and fractures: a systematic review. Drugs Aging. 2013;30(7):527-47.

81. Bodmer M, Meier C, Kraenzlin ME, Meier CR. Risk of fractures with glitazones: a critical review of the evidence to date. Drug Saf. 2009;32(7):539-47.

82. Thrailkill KM, Lumpkin CK Jr, Bunn RC, Kemp SF, Fowlkes JL. Is insulin an anabolic agent in bone? Dissecting the diabetic bone for clues. Am J Physiol Endocrinol Metab. 2005;289(5):E735-45.

83. Bortolin RH, Freire Neto FP, Arcaro CA, Bezerra JF, da Silva FS, Ururahy MA, et al. Anabolic effect of insulin therapy on the bone: osteoprotegerin and osteocalcin up-regulation in streptozotocininduced diabetic rats. Basic Clin Pharmacol Toxicol. 2017;120(3):227-34.

84. Basu R, Peterson J, Rizza R, Khosla S. Effects of physiological variations in circulating insulin levels on bone turnover in humans. J Clin Endocrinol Metab. 2011;96(5):1450-5.

85. Yang Y, Zhao C, Liang J, Yu M, Qu X. Effect of dipeptidyl peptidase-4 inhibitors on bone metabolism and the possible underlying mechanisms. Front Pharmacol. 2017;8:487.

86. Christensen MB, Lund A, Calanna S, Jorgensen NR, Holst JJ, Vilsboll $\mathrm{T}$, et al. Glucose-dependent Insulinotropic polypeptide (GIP) inhibits bone resorption independently of insulin and glycemia. J Clin Endocrinol Metab. 2018;103(1):288-94.

87. Wang C, Xiao F, Qu X, Zhai Z, Hu G, Chen X, et al. Sitagliptin, an anti-diabetic drug, suppresses estrogen deficiency-induced osteoporosisin vivo and inhibits RANKL-induced osteoclast formation and bone resorption in vitro. Front Pharmacol. 2017;8:407.

88. Bethel MA, Patel RA, Merrill P, Lokhnygina Y, Buse JB, Mentz $\mathrm{RJ}$, et al. Cardiovascular outcomes with glucagon-like peptide-1 receptor agonists in patients with type 2 diabetes: a meta-analysis. Lancet Diabetes Endocrinol. 2018;6(2):105-13.

89. Pacheco-Pantoja EL, Ranganath LR, Gallagher JA, Wilson PJ, Fraser WD. Receptors and effects of gut hormones in three osteoblastic cell lines. BMC Physiol. 2011;11:12 -6793-11-12.

90. Yamada C, Yamada Y, Tsukiyama K, Yamada K, Udagawa N, Takahashi N, et al. The murine glucagon-like peptide-1 receptor is essential for control of bone resorption. Endocrinology. 2008;149(2):574-9.

91. Hygum K, Harslof T, Jorgensen NR, Rungby J, Pedersen SB, Langdahl BL. Bone resorption is unchanged by liraglutide in type 2 diabetes patients: a randomised controlled trial. Bone. 2020;132: 115197.

92. Iepsen EW, Lundgren JR, Hartmann B, Pedersen O, Hansen T, Jorgensen NR, et al. GLP-1 receptor agonist treatment increases bone formation and prevents bone loss in weight-reduced obese women. J Clin Endocrinol Metab. 2015;100(8):2909-17.

93. Johnson KC, Bray GA, Cheskin LJ, Clark JM, Egan CM, Foreyt $\mathrm{JP}$, et al. The effect of intentional weight loss on fracture risk in persons with diabetes: results from the look AHEAD randomized clinical trial. J Bone Miner Res. 2017;32(11):2278-87. 
94. Fitchett D, Zinman B, Wanner C, Lachin JM, Hantel S, Salsali A, et al. Heart failure outcomes with empagliflozin in patients with type 2 diabetes at high cardiovascular risk: results of the EMPAREG OUTCOME(R) trial. Eur Heart J. 2016;37(19):1526-34.

95. Perkovic V, Jardine MJ, Neal B, Bompoint S, Heerspink HJL, Charytan DM, et al. Canagliflozin and renal outcomes in type 2 diabetes and nephropathy. N Engl J Med. 2019;380(24):2295306.

96. Thrailkill KM, Nyman JS, Bunn RC, Uppuganti S, Thompson KL, Lumpkin CK Jr, et al. The impact of SGLT2 inhibitors, compared with insulin, on diabetic bone disease in a mouse model of type 1 diabetes. Bone. 2017;94:141-51.

97. Ye Y, Zhao C, Liang J, Yang Y, Yu M, Qu X. Effect of sodiumglucose co-transporter 2 inhibitors on bone metabolism and fracture risk. Front Pharmacol. 2019;9:1517.

98. Bilezikian JP, Watts NB, Usiskin K, Polidori D, Fung A, Sullivan $\mathrm{D}$, et al. Evaluation of bone mineral density and bone biomarkers in patients with type 2 diabetes treated with canagliflozin. J Clin Endocrinol Metab. 2016;101(1):44-51.

99. Rosenstock J, Vico M, Wei L, Salsali A, List JF. Effects of dapagliflozin, an SGLT2 inhibitor, on $\mathrm{HbA}(1 \mathrm{c})$, body weight, and hypoglycemia risk in patients with type 2 diabetes inadequately controlled on pioglitazone monotherapy. Diabetes Care. 2012;35(7):1473-8.

100. De Laet C, Kanis JA, Odén A, Johanson H, Johnell O, Delmas P, et al. Body mass index as a predictor of fracture risk: a metaanalysis. Osteoporos Int. 2005;16(11):1330-8.

101. Søgaard AJ, Holvik K, Omsland TK, Tell GS, Dahl C, Schei B, et al. Abdominal obesity increases the risk of hip fracture. A population-based study of 43,000 women and men aged 60-79 years followed for 8 years. Cohort of Norway. J Intern Med. 2015;277(3):306-17.

102. Napoli N, Strotmeyer ES, Ensrud KE, Sellmeyer DE, Bauer DC, Hoffman AR, et al. Fracture risk in diabetic elderly men: the MrOS study. Diabetologia. 2014;57(10):2057-65.

103. Gillespie LD, Gillespie WJ, Robertson MC, Lamb SE, Cumming $\mathrm{RG}$, Rowe BH. Interventions for preventing falls in elderly people. Cochrane Database Syst Rev. 2003;(4):CD000340. https://doi. org/10.1002/14651858.CD000340.
104. Yang Y, Hu X, Zhang Q, Zou R. Diabetes mellitus and risk of falls in older adults: a systematic review and meta-analysis. Age Ageing. 2016;45(6):761-7.

105. Roman de Mettelinge T, Cambier D, Calders P, Van Den Noortgate N, Delbaere K. Understanding the relationship between type 2 diabetes mellitus and falls in older adults: a prospective cohort study. PLoS One. 2013;8(6):e67055.

106. Morrison S, Colberg SR, Parson HK, Vinik AI. Relation between risk of falling and postural sway complexity in diabetes. Gait Posture. 2012;35(4):662-8.

107. Li CI, Liu CS, Lin WY, Meng NH, Chen CC, Yang SY, Chen HJ, Lin CC, Li TC. Glycated hemoglobin level and risk of hip fracture in older people with type 2 diabetes: A competing risk analysis of taiwan diabetes cohort study. J Bone Miner Res. 2015;30(7): 1338-46. https://doi.org/10.1002/jbmr.2462.

108. Ivers RQ, Cumming RG, Mitchell P, Peduto AJ. Blue Mountains Eye Study. Diabetes and risk of fracture: the Blue Mountains Eye Study. Diabetes Care. 2001;24(7):1198-203.

109. Nakamura M, Inaba M, Yamada S, Ozaki E, Maruo S, Okuno S, et al. Association of decreased handgrip strength with reduced cortical thickness in Japanese female patients with type 2 diabetes mellitus. Sci Rep. 2018;8(1):10767 -018-29061-x.

110. Martinez-Laguna D, Tebe C, Javaid MK, Nogues X, Arden NK, Cooper $\mathrm{C}$, et al. Incident type 2 diabetes and hip fracture risk: a population-based matched cohort study. Osteoporos Int. 2015;26(2):827-33.

111. Tebe C, Martinez-Laguna D, Carbonell-Abella C, Reyes C, Moreno V, Diez-Perez A, et al. The association between type 2 diabetes mellitus, hip fracture, and post-hip fracture mortality: a multi-state cohort analysis. Osteoporos Int. 2019;30(12):2407-15.

PRISMA flow diagram adapted from From Moher D, Liberati A, Tetzlaff J, Altman DG, The PRISMA Group (2009). Preferred Reporting Items for Systematic Reviews and Meta-Analyses: The PRISMA Statement. PLoS Med 6(7): e1000097. doi:https://doi.org/10. 1371/journal.pmed1000097

Publisher's Note Springer Nature remains neutral with regard to jurisdictional claims in published maps and institutional affiliations. 